by David L. Huston, Richard S. Blewett and David C. Champion

\title{
Australia through time: a summary of its tectonic and metallogenic evolution
}

Geoscience Australia, GPO Box 378, Canberra, ACT 2601, Australia. E-mail: david.huston @ga.gov.au; richard.blewett@ga.gov.au; david.champion@ga.gov.au

The geological evolution of Australia is closely linked to supercontinent cycles that have characterised the tectonic evolution of Earth, with most geological and metallogenic events relating to supercontinent/ supercraton assembly and breakup. Australia mainly grew from $W-E$, with two major Archean cratons, the Yilgarn and Pilbara cratons, forming the oldest part of the continent in the West Australian Element. The centre of the continent consists of the mainly PaleoproterozoicMesoproterozoic North and South Australian elements, whereas the $E$ is dominated by the NeoproterozoicMesozoic Tasman Element. The West, North and South Australian elements initially assembled during the Paleoproterozoic amalgamation of Nuna, and the Tasman Element formed mostly as a Paleozoic accretionary margin during the assembly of Gondwana-Pangea. Australia's present position as a relatively stable continent resulted from the breakup of Gondwana. Australia is currently moving northward toward SE Asia, probably reflecting the earliest stages of the assembly of the next supercontinent, Amasia.

Australia's resources, both mineral and energy, are linked to its tectonic evolution and the supercontinent cycle. Australia's most important Au province is the product of the assembly of Kenorland, whereas its major $\mathrm{Zn}$-Pb-Ag deposits and iron oxide-Cu-Au deposits formed as Nuna broke up. The diverse metallogeny of the Tasman Element is a product of Pangea-Gondwana assembly and most of Australia's hydrocarbon resources are a consequence of the breakup of this supercontinent.

\section{Introduction}

Australia severed its last ties to Gondwana, separating from Antarctica at c. 34 Ma (Veevers et al., 1991), largely isolating the Australian continent from active plate margins. Rocks in Australia, however, record a complex, and contentious, geological history that can be traced back to the Eoarchean. In this contribution we present one interpretation of this history, and delve into some of the related controversies. We also link Australia's geological heritage, including its resources, as well as its geography, flora and fauna, to this tectonic narrative. Much of the geology of Australia is the consequence of the amalgamation and break-up of supercontinents and supercratons through geological time, such as Vaalbara, Kenorland, Nuna (Columbia), Rodinia and Pangea (including Gondwana) (Figure 1).

Supercontinent history has not only controlled the distribution of resources, petroleum, coal and minerals, but has surprising influences on processes that have shaped Australia in the past and are shaping Australia now. Australia, for example, shares many floral and faunal affinities with South America and Africa, but few with northern hemisphere continents (e.g., Couper, 1960; Fooden, 1972). The breakup of Pangea isolated Australia from Eurasia and North America. Moreover, when Australia broke away from Antarctica, the resulting seaway opened to allow polar circulation of ocean currents and ultimately the formation of the Antarctic ice cap (Livermore et al. 2005), making Australia, and the world, drier and cooler (Fujioka and Chappell, 2010).

Continental Australia grew predominantly from W-E, with Archean rocks mostly in the $\mathrm{W}$, Proterozoic rocks in the centre, and Phanerozoic rocks in the E. The western two-thirds of the continent consist of three mostly Precambrian elements (see Table 1 for definitions), the West Australian, North Australian and South Australia elements, whereas the eastern one-third is made up of the Tasman Element (Figure 2). These spatial and temporal growth patterns are consistent with supercontinent and supercraton growth, particularly Kenorland, Nuna and Pangea-Gondwana. The distribution of Australia's energy and mineral resources (Figure 2) is also governed by this broad pattern, with each of the four major cratonic elements characterised by distinctive deposit assemblages, both in time and in composition.

The Australian continent evolved in four broad time periods, namely: 3800-2200 Ma, 2200-1300 Ma, 1300-700 Ma, and 700-0 Ma. The first period saw the growth of nuclei about which cratonic elements grew, whereas the latter three periods involved the amalgamation and dispersal of Nuna, Rodinia and Pangea-Gondwana, respectively. In the sections below we present a history of the growth of the present-day Australian continent using this framework, although noting that in many cases there is significant uncertainty and disagreement about specific details and, indeed, about whether some of these processes occurred at all. This geohistory provides context for events that have shaped and changed Australia and the Earth, including the evolution of life and changes in the composition of the atmosphere and hydrosphere. As they have been increasingly linked to geodynamic processes, the evolution of Australia's mineral and 

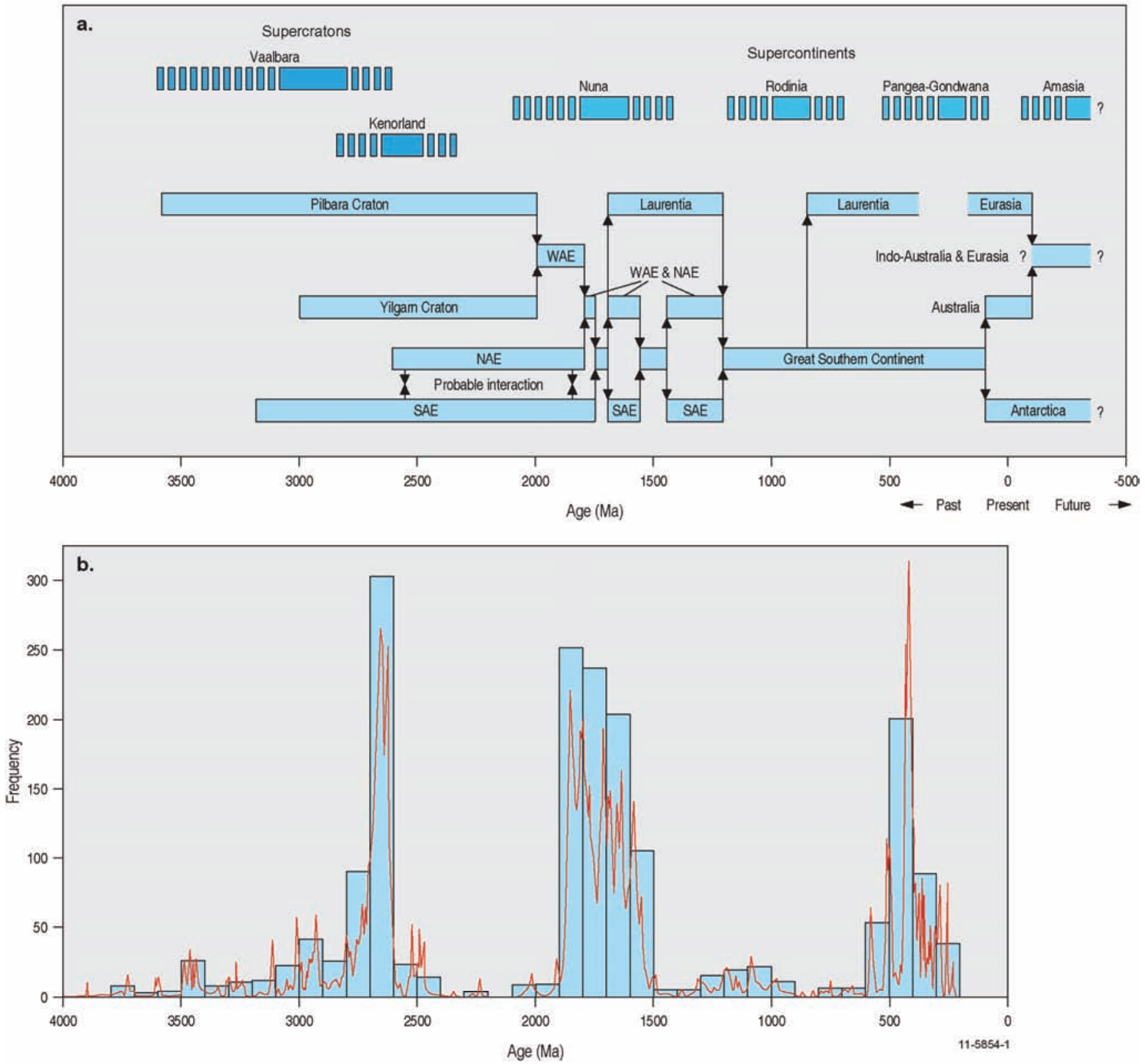

Figure 1 ( a) Assembly and breakup of cratonic elements of constitute Australia from 3.0 Ga and their relationship to supercontinent cycles. (b) Histogram showing the distribution of the age of igneous rocks from Australia as determined using SHRIMP and other U-Pb analytical techniques (data from Keith Sircombe and OZCHRON database). The acronyms NAE, SAE and WAE refer to the North, South and the West Australian elements, respectively. The upper part of Figure la shows the inferred assembly (dashed blue lines to left), stability (solid blue lines) and breakup (dashed blue lines to right) of supercontinents (light) and supercratons (dark) through time.

petroleum systems, therefore, provides a parallel framework for the evolution of the continent as a whole.

\section{0-2200 Ma: Growth of cratonic nuclei}

The oldest rocks in continental Australia, with ages between 3731$3655 \mathrm{Ma}$, consist of anorthosite and orthogneiss from the Narryer Terrane of the Yilgarn Craton (Kinny et al., 1988; Wilde et al., 2001) and from the Pilbara Craton (as xenoliths in younger plutons; Van Kranendonk et al., 2002). Although these two cratons, which form nuclei to the West Australian Element, are the most extensive exposures of old rocks in Australia, over the past five years, Archean to early Paleoproterozoic rocks have been increasingly identified within the North and South Australian Elements, forming the nuclei onto which these elements were accreted (Fraser et al., 2010; Hollis et al., 2011).

In addition to containing the oldest known rock in continental Australia, the $3731 \pm 4$ Ma Meeberrie Gneiss (Kinny et al., 1988), the Narryer Terrane contains the oldest mineral known on Earth, which is a c. 4404 Ma detrital zircon from Paleoproterozoic sedimentary rocks at Jack Hills (Wilde et al., 2001). This and other old zircons, which are only 150-350 Myr younger than the age of the Earth, have important implications for the characteristics of the earliest period of the Earth's history. Their very existence indicates that continental crust formed very early, and their heavy oxygen isotope characteristics indicate that oceans were present in the Hadean (Wilde et al., 2001). 


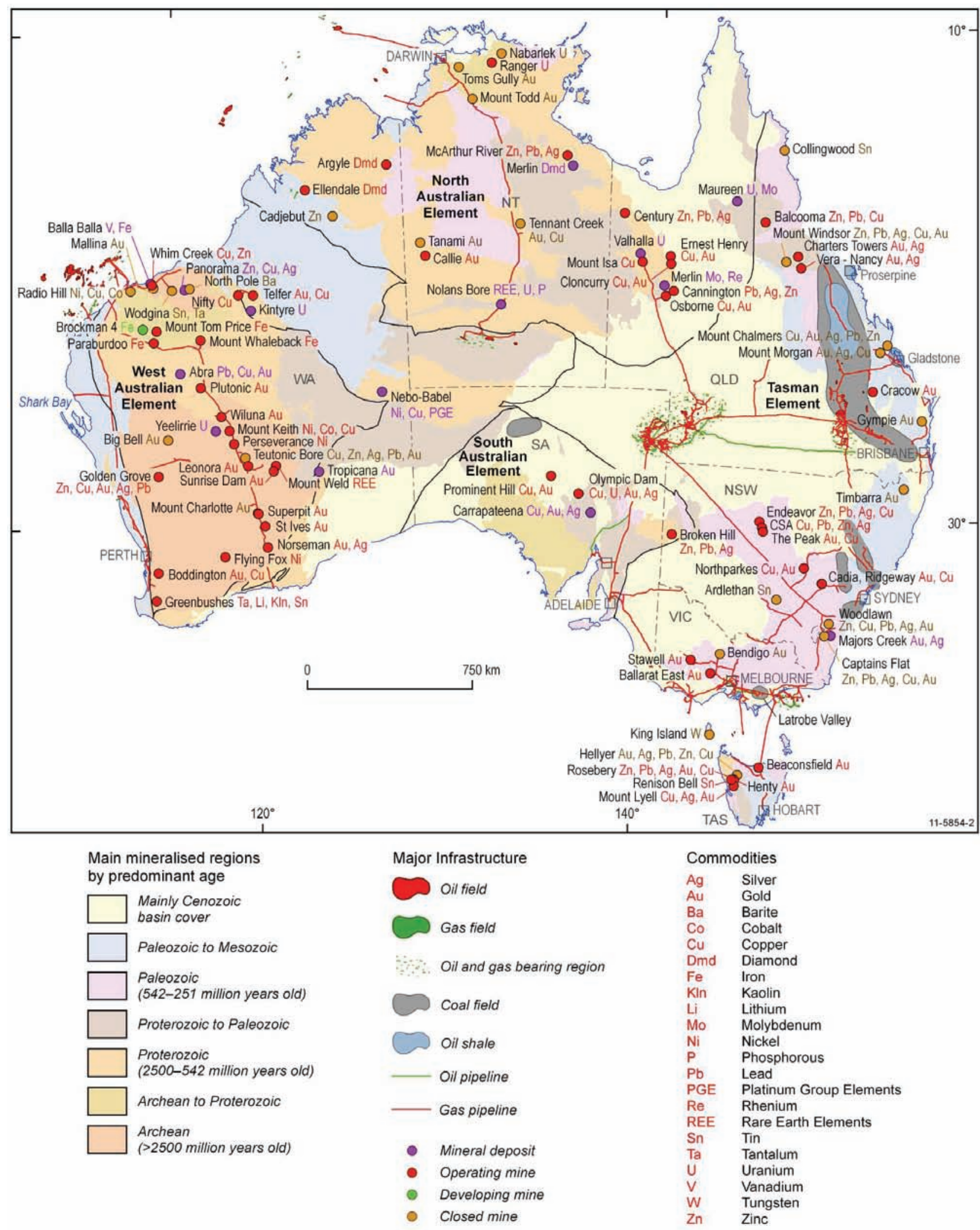

Figure 2 Distribution of Australian resources with respect to major Australian crustal elements and basins.

The Yilgarn Craton is older in the $\mathrm{W}$ than in the E. Rocks of the Narryer, Youanmi and Southwest Gneiss terranes formed between 3730-2900 Ma in the W, and those of the Kalgoorlie, Kurnalpi, Burtville and Yamarna terranes, which constitute the Eastern Goldfields Superterrane, formed between 2940-2660 Ma in the E
(Figure 3). Most tectonic reconstructions of the Eastern Goldfields Superterrane envisage arc-related accretion (e.g., Barley et al., 1989; Krapez et al., 2008), although the number of arcs and the polarity of subduction zones vary. Korsch et al. (2011a), for example, infer assembly along a series of E- and W- dipping subduction zones that 
Table 1 Definitions of terms.

\begin{tabular}{ll}
\hline Term & Definition \\
\hline Supercontinent & $\begin{array}{l}\text { A large continent formed by the amalgamation of most or } \\
\text { all of Earth's continental land masses. }\end{array}$ \\
Supercraton & $\begin{array}{l}\text { A large, ancestral (largely Archean) land-mass consisting } \\
\text { of two or more cratons. }\end{array}$ \\
Continent & $\begin{array}{l}\text { One of Earth's major land masses (or former major land } \\
\text { masses) }\end{array}$
\end{tabular}

Element Part of a continent that has some shared broad-scale geological history; often an interpreted proto-continent or collection of such continental fragments (including cratons), that now forms part of an extant continent.

Craton A part of Earth's continental crust that has attained stability and has been little deformed for a prolonged period.

Province A large geological region showing similarities in its geological history, but with a different geological history to adjacent provinces.

Superterrane A collection of two or more terranes.

Terrane A region with essentially similar geology and geological history.

Domain A, usually fault-bounded, region of similar geology.

Superbasin A group of temporally- and genetically-related basins.

Basin A low area at the Earth's surface and of tectonic origin in which sediments have accumulated.

Inlier An exposure of basement rocks completely surrounded by younger basinal rocks.

Seismic province A discrete volume of middle to lower crust, which cannot be traced to the surface, and whose crustal reflectivity is different to that of adjoining provinces, either laterally or vertically.

Orogen An, often linear or arcuate, region that has been subjected to one or more common episodes of deformation and metamorphism (orogenies).

Orogeny Geological event or genetically and temporally closely related events involving rock deformation.

Movement Geological event or genetically and temporally closely related events involving rock deformation. Used where previously defined orogenies (e.g., Alice Springs) are found to include unrelated orogenic events.

Event A temporally- and, commonly, spatially-restricted occurrence of a geological process or related geological processes. This can include magmatism (igneous event), deformation (deformational event, orogeny or movement) or mineralisation (mineralisation event).

closed between 2780-2655 Ma (Figure 3). Alternatively, Czarnota et al. (2010) inferred the growth of the Eastern Goldfields Superterrane to be related to a long-lived W-dipping subduction zone to the $\mathrm{E}$ of the Burtville Terrane. The accretionary processes were likely to have some broad similarities to modern subduction processes, with the formation of backarc basins and major orogenic events as fragments collided (Barley et al., 1989; Figure 3). These processes produced laterally continuous crust-penetrating shear zones which accessed a mantle that was fertilised by subduction. These shear zones were important conduits for Au mineralisation (Blewett et al., 2010), and may be one of the keys to the Au riches of the Eastern Goldfields Superterrane.

The Yilgarn Craton, which includes the Eastern Goldfields

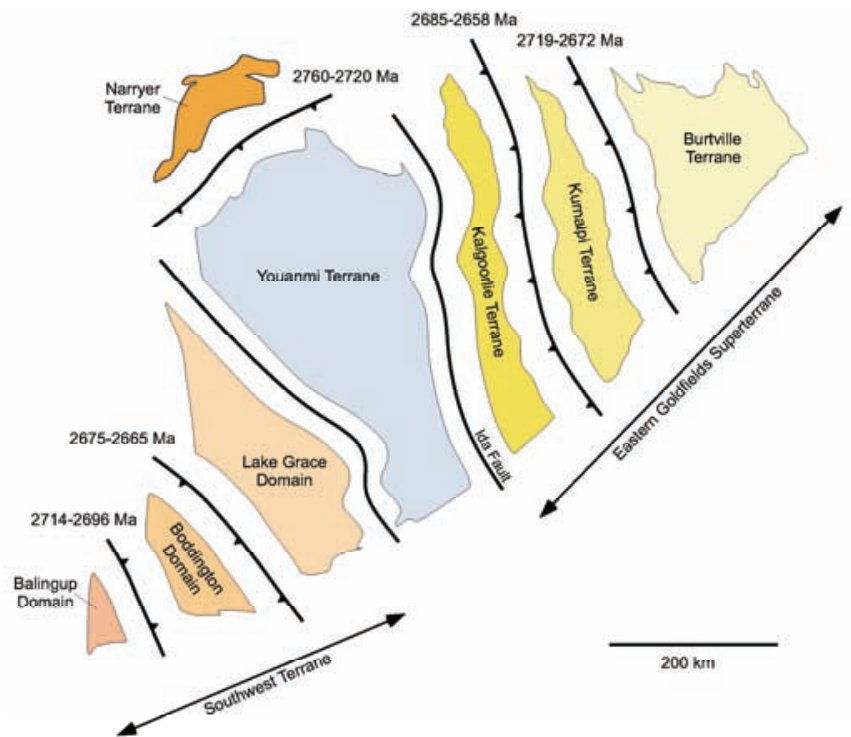

Figure 3 A model for the assembly of the Yilgarn Craton (based upon Korsch et al., 2011a). The relationships of the Southwest Terrane (Lake Grace Domain) and the Eastern Goldfields Superterrane (Kalgoorlie Terrane) to the Youanmi Terrane are uncertain.

Superterrane, has a global resource (production and reserves) in excess of 8,500 tonnes of $\mathrm{Au}$ and is one of the two largest global Archean $\mathrm{Au}$ provinces. Although most deposits in the Yilgarn Craton, particularly those in the Eastern Goldfields Superterrane, are considered lode $\mathrm{Au}$ deposits, the Boddington $\mathrm{Au}-\mathrm{Cu}$ deposit, which is located in the 2714-2696 Ma Saddleback island arc (Qiu et al., 1997; Korsch et al., 2011a) in the SW part of the craton (Figure 3), is considered to be polygenetic (McCuaig et al., 2001). The earliest phase of mineralisation, at c. $2707 \mathrm{Ma}$, is interpreted as a porphyry-style, whereas the second phase of mineralisation, at c. $2629 \mathrm{Ma}$, has a similar age to lode Au mineralisation in the Eastern Goldfields Superterrane (Stein et al., 2001). The first, porphyry-related, stage is one of the earliest examples of arc-related mineralisation known. The Yilgarn Craton is also a major Ni province (Figure 4). Individual Ni deposits are hosted by komatiites, which are high-temperature ultramafic volcanic and shallow intrusive rocks thought to be a product of a hotter Archean Earth (Nisbet et al., 1993).

The Yilgarn Craton appears to have been a constituent of the Kenorland supercraton, which is thought to have also included the Abitibi Subprovince in Canada. These two provinces formed over the same time period, and are the two most richly mineralised Archean provinces known. Kenorland had amalgamated by c. $2660 \mathrm{Ma}$ and began to break up at c. $2480 \mathrm{Ma}$ (Barley et al., 2005).

The 3530-2930 Ma Pilbara Craton is overlain by the 2780-2450 Ma Fortescue and Hamersley basins (Figure 5). Mechanisms by which the oldest $(>3200 \mathrm{Ma}$ ) part of the Pilbara Craton formed are controversial, ranging from crustal overturn (Van Kranendonk et al., 2002), to formation of an oceanic plateau as the consequence of mantle plume activity (Smithies et al., 2005a), and to tectonic processes analogous to modern plate tectonics (Bickle et al., 1983; Barley et al., 1984; Zegers et al., 1996; Blewett, 2002). By c. 3120 Ma, however, plate-tectonic-like processes must have been active, as the Whundo greenstone belt (Figure 5) is the oldest oceanic arc system known in Australia and one of the earliest known in the world (Smithies et al., 2005b). 
Age (Ma)

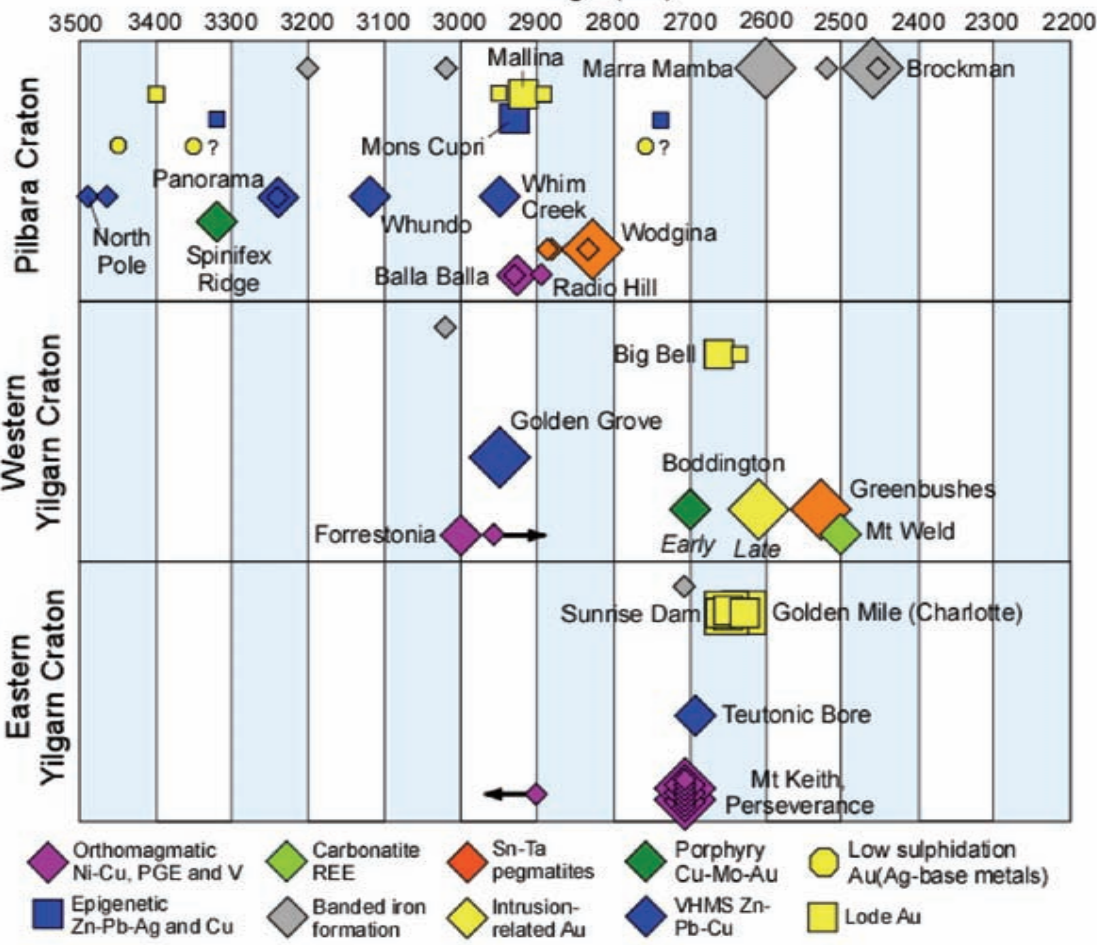

Figure 4 Major mineral deposits of Australia formed between 3500-2200 Ma (see Figure 2 for localities of named deposits). All deposits of this age occur in the West Australian Element. VHMS = volcanic-hosted massive sulfide. The size of symbols indicates the relative size of the deposits.

Being one of the best preserved blocks of old crust known on the Earth, the Pilbara Craton contains the earliest evidence of many modern geological processes. For example, the oldest unconformity is preserved by the c. 3430 Ma Strelley Pool Formation (Buick et al., 1995). This highly angular unconformity (Figure 6) overlies the earliest known weathering (regolith) profile. The Pilbara Craton contains the earliest unequivocal evidence of life on the earth, stromatolites hosted by the c. 3490 Ma Dresser Formation (Walter et al., 1980). The Dresser Formation also hosts the oldest ore deposit the North Pole barite deposit (Figure 4), which produced 129,000 tonnes of barite for use as drilling mud in the NW Shelf petroleum province. The stromatolites are commonly closely associated with hydrothermal barite (Van Kranendonk et al., 2008), which supports the idea that life might have initially evolved in a hydrothermal environment (Baross and Hoffman, 1985).

Although they are generally small and of little economic interest, the Pilbara Craton contains the oldest examples of many types of mineral deposits (Figure 4), including volcanic-hosted massive sulfide, lode $\mathrm{Au}$, epithermal precious metal and porphyry $\mathrm{Cu}$ deposits (Huston et al., 2007; Hickman and Van Kranendonk, 2012). These deposits share many features with geologically young examples, indicating that many mineralising processes have persisted throughout geological time. The oldest known hydrocarbons, within ore-related fluid inclusions, are associated with c. 3240 Ma volcanic-hosted massive sulfide deposits in the Panorama district (Rasmussen and Buick, 2000).

The Pilbara Craton was probably a constituent of the oldest supercraton, Vaalbara. This supercraton, which was made up of the Pilbara Craton and the Kaapvaal Craton in southern Africa began to form by $3600 \mathrm{Ma}$, and began to break up just after $2800 \mathrm{Ma}$ (Zegers et al., 1998; Barley et al., 2005). In comparison with supercontinents, supercratons, which probably were smaller than most modern continents, appear to have been longer lived. The c. 2800 Ma breakup of Vaalbara (Barley et al., 2005) led to the formation of the Fortescue and Hamersley basins, and their equivalents in southern Africa. Rocks in these basins constitute the Earth's earliest preserved passive margin successions (Bradley, 2008). The basin fill is dominated by thick successions of mafic and felsic volcanic rocks and of sedimentary rocks, the most important being the banded-iron formations (Nelson et al., 1999). These 2590-2450 Ma banded-iron formations (Figure 4) formed when reduced $\mathrm{Fe}^{2+}$ rich bottom waters were oxidised as they welled up onto the wide passive margin, depositing the iron (e.g., Cloud, 1973). The vast majority of Australia's and the world's banded-iron formations were deposited between c. 2600-1800 Ma, during a period when the Earth's hydrosphere was mostly oxygen-poor (Bekker et al., 2010).

The Yilgarn and Pilbara cratons differ in a number of important ways. Although both cratons have extended geological histories, the Yilgarn Craton is characterised by short period, even catastrophic, crust-forming events. This is shown in Figure 1b, in which a short sharp peak in the ages of igneous rocks corresponds to the final assembly of the Yilgarn Craton between 2720-2655 Ma. In contrast, the period between $3500-2850 \mathrm{Ma}$ is marked by several small indistinct peaks, which may reflect a slower rate of overall crustal growth, particularly in the Pilbara Craton. This pattern is also seen in global data, with the largest peak in juvenile crust between 2700 $2600 \mathrm{Ma}$, and a more diffuse peak at 3000-2800 Ma (Condie, 2005). Hawkesworth et al. (2010), however, noted that these peaks correspond to 'a particular stage in the cooling of the Earth', and possibly to a change in the mode of mantle convection (Korenaga, 2006).

In the North and South Australian elements, recent geochronology has indicated that Archean nuclei of these elements are more widespread and older than previously thought. For example, the recent identification of c. $3150 \mathrm{Ma}$ granites in the South Australian Element extends its geological history by c. $600 \mathrm{Myr}$ (Fraser et al., 2010). Recent dating has also greatly increased the extent of known Archean rocks in the North Australian Element (Hollis et al., 2011). Taken together, these new data indicate a much more significant and prolonged Archean history in both the North and South Australian elements; a history that will become clearer as more data are collected.

\section{0-1300 Ma: Amalgamation and breakup of Nuna}

The Paleoproterozoic-Mesoproterozoic evolution of the Australian continent is also controversial. Tectonic models fall into two broad groups, 'fixist' or 'mobilist'. The fixist models (e.g., Etheridge et al., 1987) suggest little lateral movement between crustal blocks, whereas the mobilist models (e.g., Giles et al., 2004; Betts 


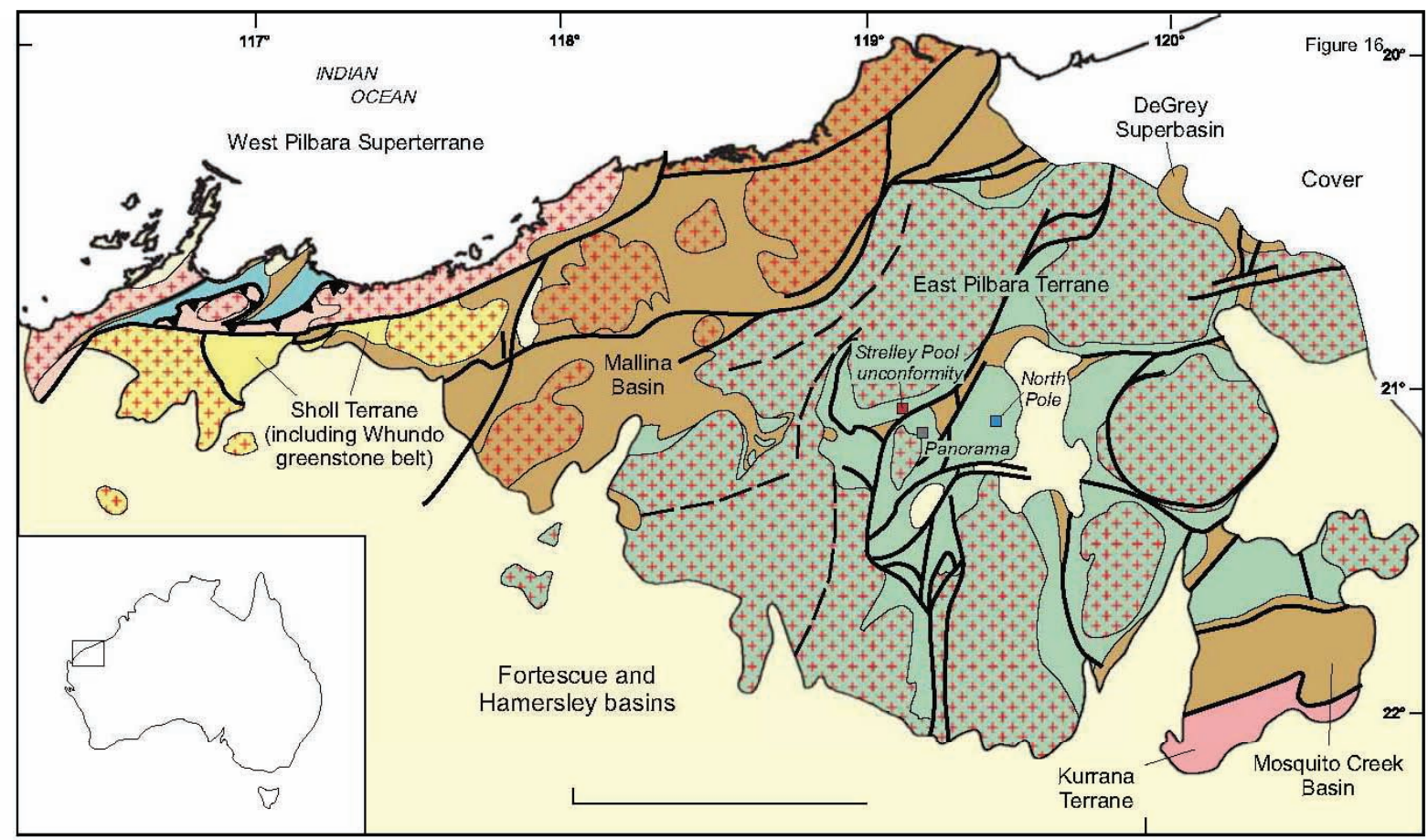

De Grey Superbasin (includes Mallina Mosquito Creek Basins: 3020-2930 Ma)

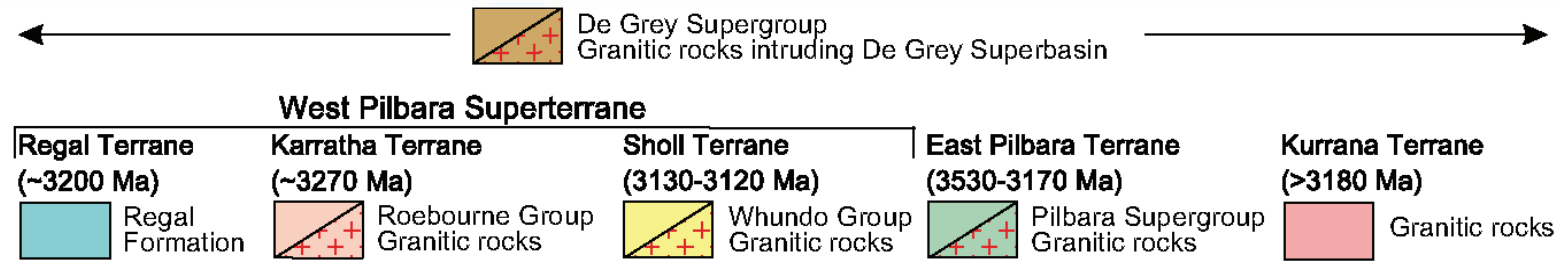

Figure 5 The geology of the Pilbara Craton (modified after Champion and Smithies, 2007).

and Giles, 2006; Cawood and Korsch, 2008) suggest large lateral movements occurred between crustal blocks. We have adopted a mobilist model that infers that the three major Precambrian elements of Australia were mostly assembled in the Paleoproterozoic as part of the supercontinent Nuna. However, there remain significant

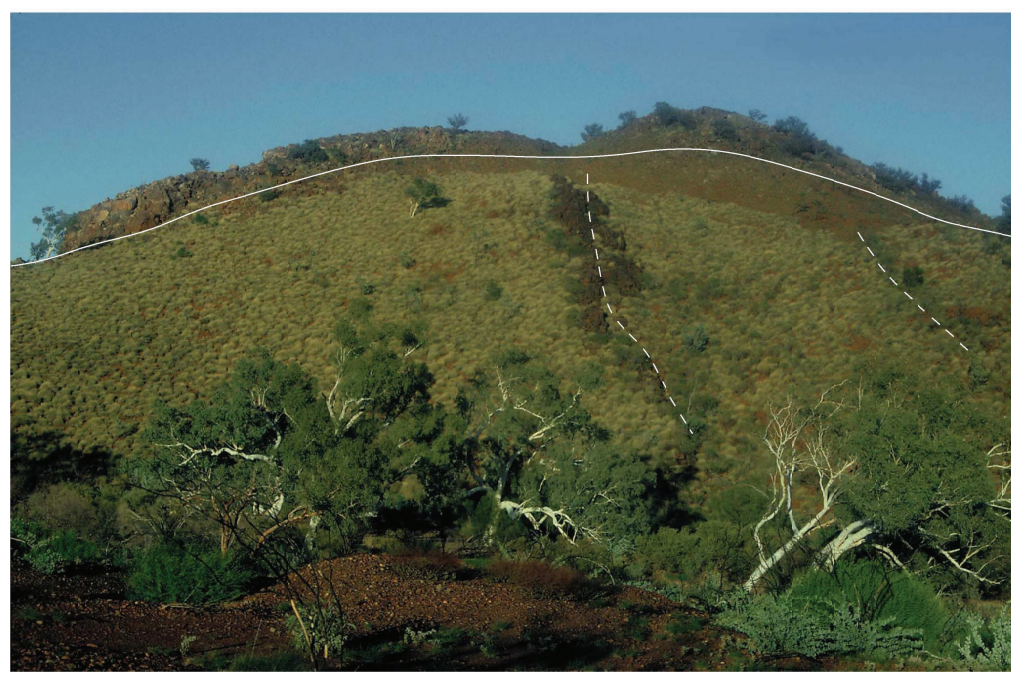

Figure 6 The Strelley Pool unconformity, a highly angular unconformity (solid white line) between the 3515-3498 Ma lower Warrawoona Group (formerly Coonterunah Group; dashed white lines show strike) and the 3350 3319 Ma Kelley Group. differences of opinion regarding the details of this assembly (Myers et al., 1996; Betts and Giles, 2006; Cawood and Korsch, 2008). We have followed the concept that the southern margin of the North Australian Element was a convergent margin through the late Paleoproterozoic-early Mesoproterozoic (Scott et al., 2000; Giles et al., 2002). Although this is consistent with the broad model of Betts and Giles (2006), alternative models have been proposed (Gibson et al., 2008; Payne et al., 2009). In many cases, the boundaries between provinces are determined in part based upon contrasts in seismic and/or magnetotelluric data.

\section{0-1700 Ma: Amalgamation of Nuna}

The Pilbara and Yilgarn cratons were amalgamated by a series of tectonic events from 2215-1950 Ma that affected the Capricorn Orogen and amalgamated the West Australian Element (Cawood and Tyler, 2004), which is one of the earliest building blocks of Nuna (Figures 1 and 7). Most of the North Australian Element formed before $1840 \mathrm{Ma}$ as a consequence of the amalgamation of the combined TanamiTennant-Isa Province with the combined Kimberley-Pine Creek Province at c. $1840 \mathrm{Ma}$ from the W, the NumilAbingdon Seismic Province from the E before $1850 \mathrm{Ma}$, and the Aileron Province from the S before $1840 \mathrm{Ma}$ (Figures 1 and 7; Sheppard et al., 1999; Tyler and Sheppard, 2006; 


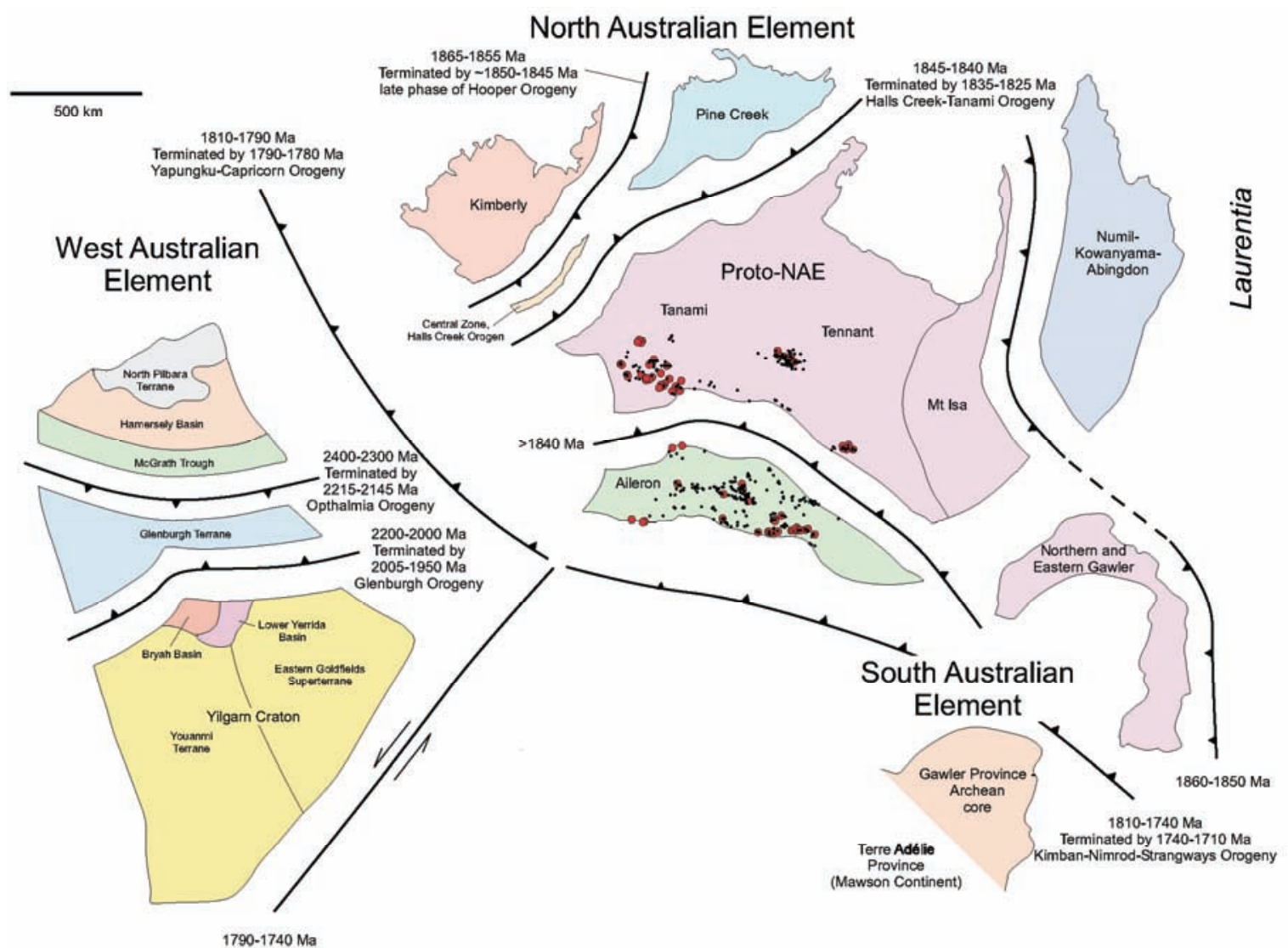

Figure 7 An interpretation of the assembly of proto-Australia. The circles indicate analyses of 1820-1710 Ma granites from the southern part of the North Australian Element. The larger red circles indicate sodic $\left(\geq 3.5 \% \mathrm{Na}_{2} \mathrm{O}\right)$ granite analyses, which are also characterised by high Sr, low $\mathrm{Y}$ and high $\mathrm{Sr} / \mathrm{Y}$ ratios typical of subduction-related granites.

Goleby et al., 2009; Korsch et al., 2012). Along the southern margin of the proto-North Australian Element (Figure 7), c. 1865 Ma turbiditic rocks of the Warramunga Formation (Compston, 1995) and Stubbins Formation (Bagas et al., 2008), may have formed in backarc basins associated with the northward convergence of the Aileron Province.

The northern and eastern parts of Gawler Province, which forms the core of the South Australian Element, grew, at least in part, as a consequence of subduction from the E, and may have been originally part of the North Australian Element (Figures 1 and 7; Payne et al., 2009). This interpretation is consistent with studies by Payne et al. (2006) that indicate the provenance of sediments from the northern and eastern Gawler Province is consistent with a source in the Isa Province, but not the Archean core of the Gawler Province.

By c. $1840 \mathrm{Ma}$, most of the West and North Australian Elements had been assembled. Although the North and South Australian Elements may have been together intermittently since c. $2500 \mathrm{Ma}$ (Figure 1; Payne et al., 2009), the period between 1810-1750 Ma saw the assembly of two and possibly three Paleoproterozoic-Archean elements into the proto-Australian continent (Figure 7). Beginning at c. $1810 \mathrm{Ma}, \mathrm{N}$ - to NE-directed subduction along the southern margin of the North Australian Element resulted in convergence between the North Australian Element and the West Australian Element and the Archean core of the Gawler Province. The West Australian Element was first to dock with the North Australian Element at c. 17901780 Ma during the Yapungku-Capricorn Orogeny (Bagas, 2004). After this collision, $\mathrm{N}$-directed subduction continued underneath the the North Australian Element, possibly with a sinistral strike-slip fault developing along the SE margin of the West Australian Element (Figure 7). This period of convergence concluded when the Archean core of the Gawler Province (Figure 7) was accreted onto the combined North and West Australian Element during the Kimban-Nimrod-Strangways Orogeny at 1740-1690 Ma (Betts et al., 2008).

This interpretation is supported by the emplacement of sodic granites and by the formation of mineral deposits characteristic of convergent margins along the southern margin of the North Australian Element. Two discrete belts of sodic granites are present along this margin. An older belt is located in the southern part of the W-NWtrending, 1815-1795 Ma magmatic belt in the Tanami-Tennant-Isa Province (Figure 7). A second, E-W trending belt occurs along the southern margin of the Aileron Province associated with the 17901750 Ma granites (i.e., the calc-alkaline-tonalite (CAT) suite of Zhao and McCulloch, 1995). Lode Au deposits (1810-1795 Ma; Cross et al., 2005) and volcanic-hosted massive sulfide (1810-1765 Ma; Hussey et al., 2005), which typically form along convergent margins, developed in the southern part of the North Australian Element. It is likely that Laurentia was joined to the proto-Australian continent on the E until at least $1690 \mathrm{Ma}$ (Betts and Giles, 2006).

\section{0-1300 Ma: Breakup of Nuna}

Shortly thereafter, Nuna began to break up. This process, however, was complicated and involved rifting of Laurentia to the $\mathrm{E}$ of protoAustralia, but development of a backarc basin system along the 
southern margin of Proterozoic Australia as subduction stepped to the S (Figure 8; Scott et al., 2000; Giles et al., 2002; Betts et al., 2003). The earliest evidence of extensional processes is the emplacement of 1710-1685 Ma layered mafic-ultramafic intrusions within the southern part of the Aileron Province (Claoué-Long and Hoatson, 2005). The development of basins filled with turbidites and emplacement of tholeiitic mafic rocks along the eastern margins of the South Australian Element in the Curnamona Province and the North Australian Element (Willis et al., 1983; Beardsmore et al., 1988) suggest extension along the eastern margin of Proterozoic Australia beginning at c. $1690 \mathrm{Ma}$ (Betts et al., 2003; Gibson et al., 2008; Figure 8 ). This extension produced the Calvert and Isa superbasins (Southgate et al., 2000), which, together with the related Curnamona Province, are hosts to the Australian Proterozoic Zn belt. Ultimately it also resulted in the separation of proto-Australia and Laurentia (Betts et al., 2003), with final separation occurring to the $\mathrm{E}$ of the Numil-Kowanyama-Abingdon Province in Queensland (Figure 8).

Beginning at c. $1690 \mathrm{Ma}$, felsic magmatic rocks and minor
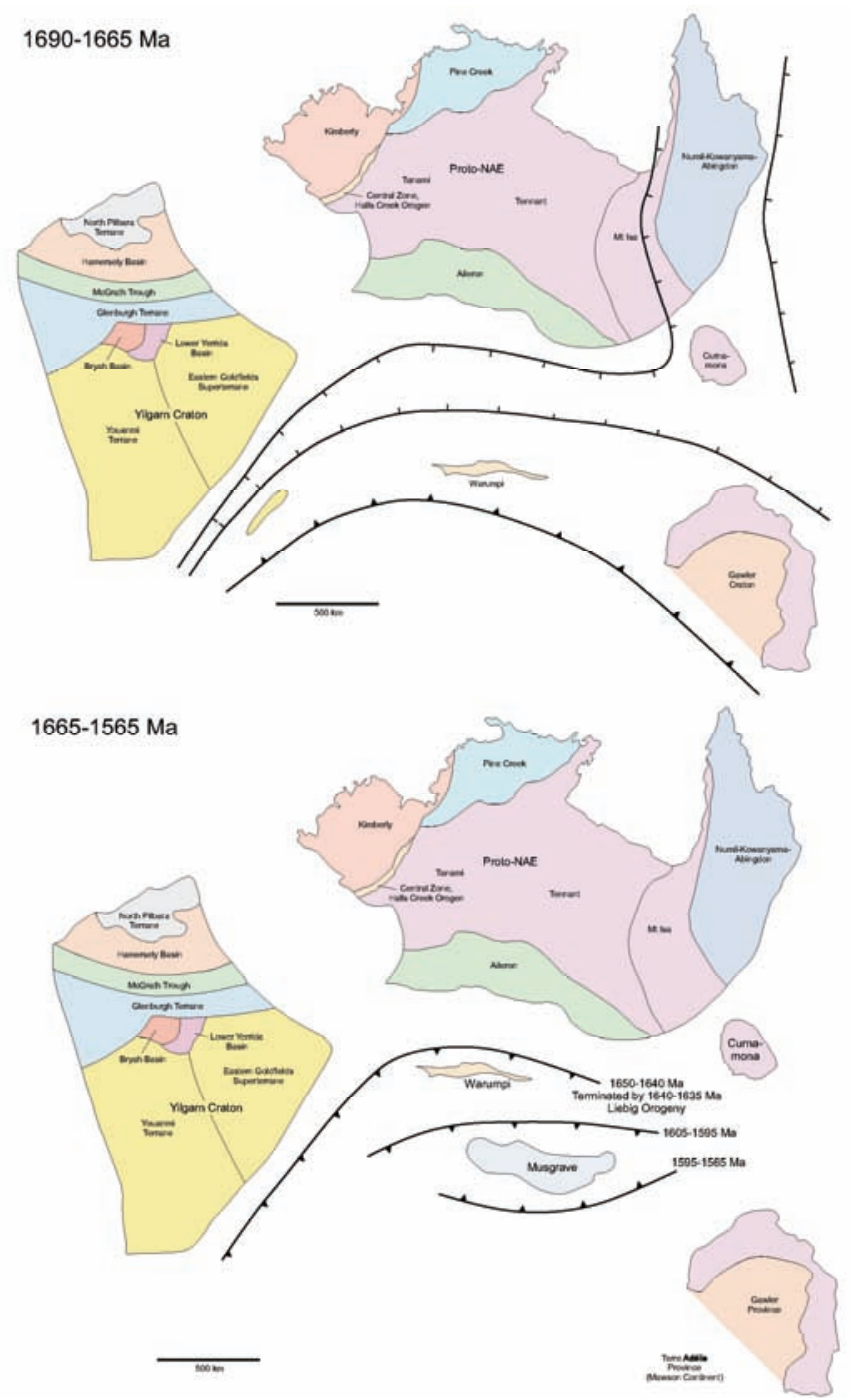

Figure 8 An interpretation of the evolution of proto-Australia from 1690-1565 Ma. This involved extension along the eastern margin of proto-Australia and separation from Laurentia (1690-1665 Ma) and convergence along the southern margin of the combined North and West Australian elements (1665-1565 Ma). sedimentary rocks, now orthogneiss and paragneiss, were deposited as the oldest known rocks in the Warumpi Province (Scrimgeour et al., 2005). In addition, Kirkland et al. (2011) inferred convergence and the development of backarc basins along the SE margin of the West Australian Element between 1710-1665 Ma. The inference of $\mathrm{N}$-dipping subduction is supported by $1690-1665$ Ma granitic rocks with arc-like geochemical signatures in this region (Eddy Suite; Kirkland et al., 2011) and the Warumpi Province (Argilke Suite; Cawood and Korsch, 2008).

At c. $1660 \mathrm{Ma}$, this continental margin backarc basin system began to close through a series of both S- and N-directed subduction systems that led to the accretion of rocks of the Warumpi Province at c. 1640 Ma (Scrimgeour et al., 2005), followed by those of the Musgrave Province at c. $1590 \mathrm{Ma}$ (Wade et al., 2006), and those of the Gawler Province at c. $1560 \mathrm{Ma}$ (Korsch et al., 2011a). During this period, the Gawler Province was likely the northern extension of the Mawson Continent, which also included the Terre Adélie Craton and large parts of the East Antarctic Shield (e.g., Boger, 2011), although Swain et al. (2008) suggested that the Terre Adélie Craton accreted onto the Gawler Province at c. $1610 \mathrm{Ma}$, following NE-dipping subduction. At some time after c. $1560 \mathrm{Ma}$, the Mawson Continent (including the Gawler and Curnamona provinces) must have rifted from protoAustralia as these elements converged again during the assembly of Rodinia (Giles et al., 2004).

The period 1640-1500 Ma also involved episodic deformation through much of Proterozoic Australia. The earliest deformational event system, at c. 1640-1635 Ma, affected only the North Australian Element, and involved N-S-directed contraction along the southern margin (Liebig Orogeny; Scrimgeour et al., 2005) and in the E (Riversleigh inversion; Geological Survey of Queensland, 2011). This event may be the result of the accretion of the Warumpi Province (Figure 8; Scrimgeour et al., 2005) and is marked by a U-turn on the North Australian apparent polar wander path (Idnurn, 2000; Figure 9).

Between 1605-1585 Ma, the Isa (early phase of the Isan Orogeny; Geological Survey of Queensland, 2011), Aileron (early part of the Chewings Orogeny; Rubatto et al., 2001) and Curnamona provinces (Olarian Orogeny; Page et al., 2005) were affected by contractional deformation. In the Isa Province, this event was a N-S to NW-SE directed crustal-shortening event (Geological Survey of Queensland, 2011) and may relate to accretion of the Musgrave Province (Figure 8).

Similarly, the northern part of the Gawler Province was affected by high pressure metamorphism at this time (Cutts et al., 2011), although this deformation is not known to extend into the Archean core of the province. Rather, the central part of the Gawler Province is characterised by the emplacement of the 1595-1575 Ma Hiltaba magmatic province, which includes the felsic-dominated Gawler Range Volcanics and coeval Hiltaba granite suite. Betts et al. (2007) interpreted this magmatic event to be the consequence of a migrating hot spot or plume, and the timing of magmatism corresponds to a shift from a contractional to an extensional tectonic environment (Skirrow, 2010). The Chewings Orogeny in the Aileron Province, which is largely a low pressure-high temperature magmatic event continued until $1560 \mathrm{Ma}$ (Rubatto et al., 2001), may be a consequence of backarc extension related to convergence between the Gawler Province and the North Australian Element (Korsch et al., 2011a; Figure 8).

After c. $1570 \mathrm{Ma}$, thermotectonic activity mostly contracted to 


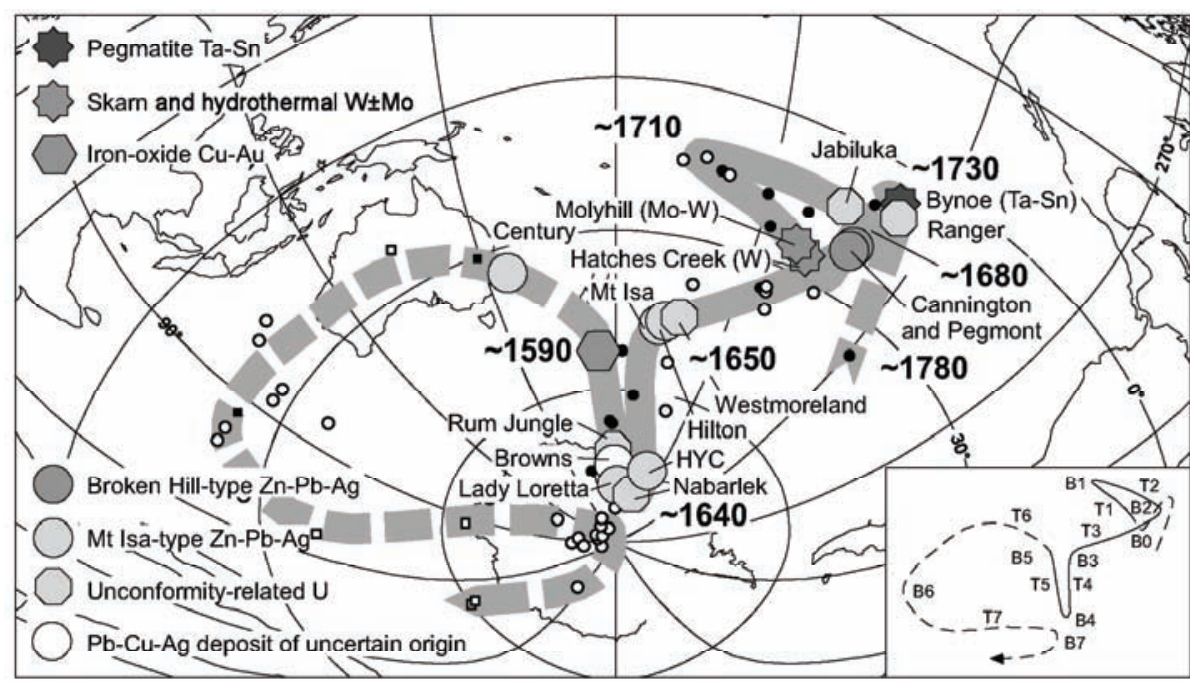

Figure 9 Variations in the apparent polar wander path for the North Australian Element during the late Paleoproterozoic to the early Mesoproterozoic showing relationships to the timing of major ore deposits (modified after Idnurm et al., 2000). Dashed lines indicate uncertain parts of the wander path.

eastern Proterozoic Australia, although restricted activity occurred in the Gawler and Curnamona provinces. The 1560-1540 Ma Middle Isan Orogeny (and the Jana Orogeny further to the E), which involved E-W contraction, may relate to convergence between Australia and Laurentia (Geological Survey of Queensland, 2011). Emplacement of the 1545-1500 Ma anorogenic Williams Suite and associated deformation may relate to hot spot movement (Betts et al., 2007).

A large part of Australia's mineral wealth, particularly Fe ore and base metals, formed during the amalgamation and breakup of Nuna (Figure 10). Upgrading of Fe ore deposits in the Hamersley Basin (c. $2008 \mathrm{Ma}$; Müller et al., 2005), and formation of lode Au deposits in the Pine Creek and Tanami provinces (c. 1810-1790 Ma; Compston and Matthai, 1994; Cross et al., 2005) occurred during amalgamation (Figure 7). In contrast, $\mathrm{Zn}-\mathrm{Pb}-\mathrm{Ag}$ deposits of the Australian Proterozoic Zn belt (1690-1575 Ma; Betts et al., 2003; Leach et al., 2010) formed during breakup (Figure 10), and deposits of the iron oxide-Cu-Au deposits in the Olympic Dam (c. 1575 Ma; Skirrow et al., 2007) and Cloncurry mineral provinces (mostly 1530-1500 Ma; Duncan et al., 2011) may relate to a migrating hot spot or plume (Betts et al., 2007). In the North Australian Element, the timing of formation of many deposits corresponds to bends in the Australian apparent polar wander path (Figure 9; Idnurm, 2000). These bends are responses to changes in plate motion and/or plate reorganisation associated with large-scale tectonic processes, for example at c. 1640-1590 Ma.

The Mesoproterozoic was also a time for the generation of abundant high heatproducing granite magmatism and felsic volcanism rock (Neumann et al., 2000). The resulting rocks contribute to Australia's crustal heat production today, providing a thermal resource for geothermal power as well as a uranium resource for nuclear power. Another curiosity of this time is the development of the world's oldest oil play, although in uneconomic quantities, in the Upper Roper Group of the Mesoproterozoic McArthur Basin, NW of Mount Isa (Jackson et al., 1986).

Iron ore deposits in the Hamersley Basin are unusual relative to other ore deposits in Australia in that they formed as the consequence of three geological events, which were several hundreds of millions to billions of years apart, and occurred in quite different geological environments. Banded-iron formation proto-ore, deposited prior to the Great Oxidation Event (2450-2090 Ma; Farquhar et al., 2010), was upgraded by oxidised, basinal brines at c. $2008 \mathrm{Ma}$ (Müller et al., 2005), which oxidised the Fe and removed $\mathrm{Si}$ and carbonate. Then paleoweathering removed $\mathrm{P}$, leaving high-grade, direct shipping ore (Barley et al., 1999; Taylor et al., 2001).

\section{0-700 Ma: Amalgamation and breakup of Rodinia}

Globally, the period between 1300-700 Ma saw the assembly and breakup of the second supercontinent, Rodinia (Figure 11). In Australia, this period was characterised by crustal reworking in the Albany-Fraser-Musgrave belt and the later formation of the intracratonic Central Australian Basin System. New discoveries and more data from existing mineral deposits indicate the presence of important mineralising events during this period, albeit of different character to other times during Australia's history.

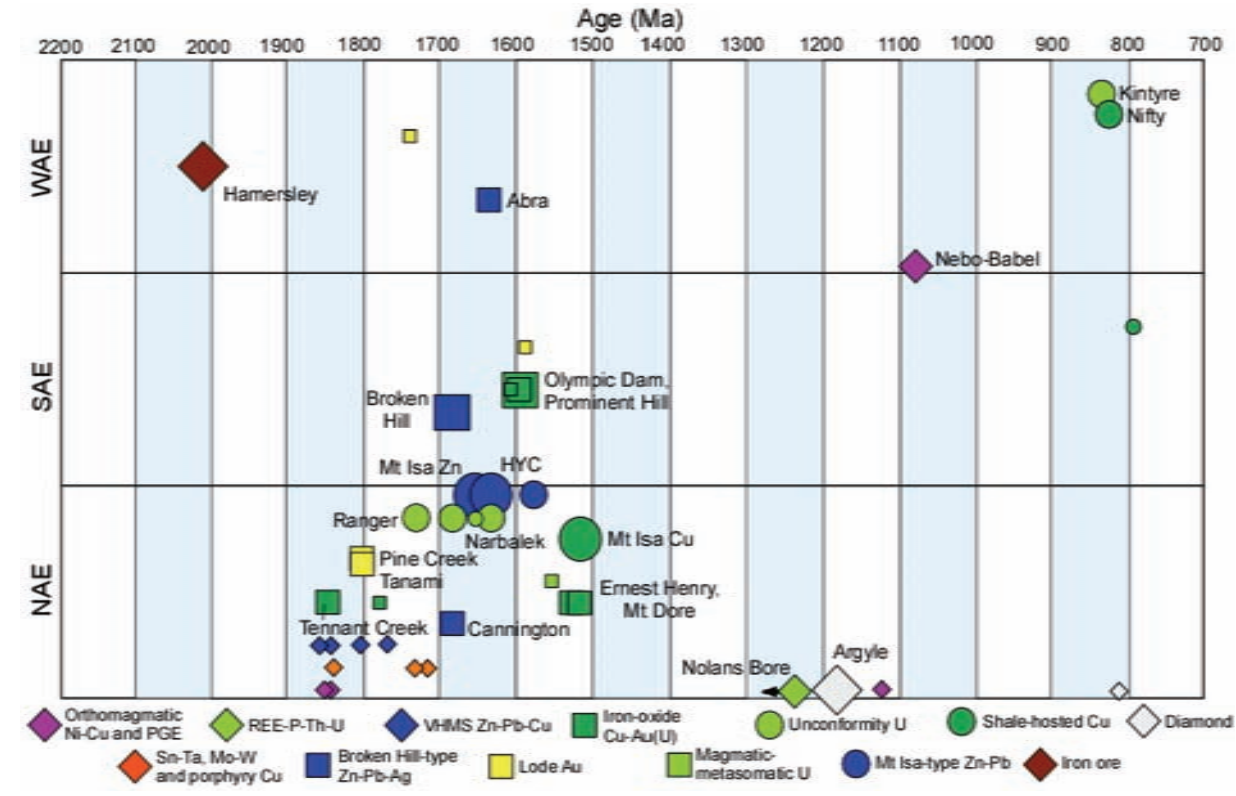

Figure 10 Major mineral deposits of Australia formed between 2200-700 Ma. See Figure 2 for localities of named deposits and Figure 4 for explanation of acronyms and symbol size. 

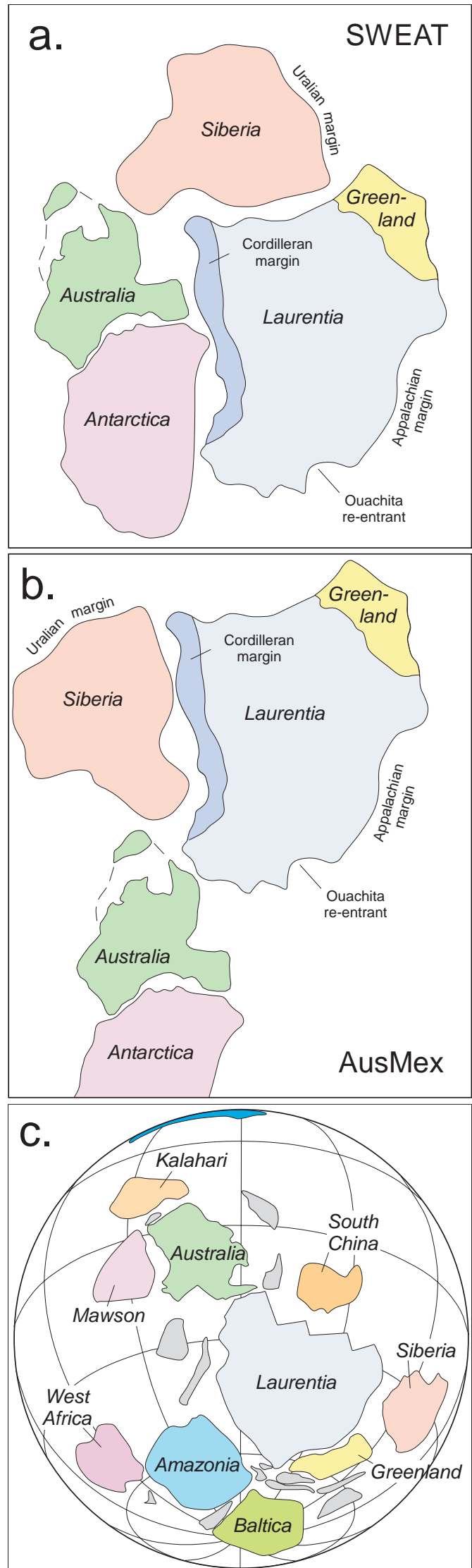

Figure 11 Possible reconstructions of Rodinia. (a) the SWEAT (Southwest (US) - East Antarctic: Hoffman, 1991) reconstruction. (b) the Ausmex (Australia-Mexico: Wingate et al., 2002) reconstruction. (c) the modified AusMex (Pisarevski et al., 2003) model.
The earliest major events that affected Australia during the 1300 700 Ma period were a series of deformational events that overprinted the Albany-Fraser and Musgrave orogens between 1345-1140 Ma (Myers et al., 1996; Smithies et al., 2010; Kirkland et al., 2011). These events probably relate to the collision of the combined WestNorth Australian Element with the Mawson Craton, which includes the South Australian Element and the East Antarctica Shield (Boger, 2011). This collision was a prelude to the assembly of Rodinia, which was mainly assembled between 1100-980 Ma (Pisarevsky et al., 2003).

Mineral deposits that formed prior to and during the assembly of Rodinia are quite diverse, and include diamond, REE and orthomagmatic Ni-Cu-PGE deposits (Figure 10). The diamond and REE deposits are associated with alkalic rocks, including the c. 1178 Ma Argyle diamond pipe (Pidgeon et al., 1989), which may be the result of an intracratonic plume event. The volcanic-hosted massive sulfide and lode $\mathrm{Au}$ deposits that characterise the assembly of earlier (Kenorland and Nuna) and later (Pangea-Gondwana) supercontinents/ supercratons are missing, both in Australia and overseas, which suggests important differences in the geodynamic processes that accompanied growth of Rodinia compared to those that were associated with the growth of Nuna and Pangea-Gondwana.

Rifting leading to the breakup of Rodinia commenced c. $850 \mathrm{Ma}$ with final breakup at c. $750 \mathrm{Ma}$. One of the earliest manifestations of this process in Australia is the NW-trending c. 830 Ma Gairdner Large Igneous Province (Wingate et al., 1998), which intruded the South and North Australian Elements and extended to the Paterson Orogen in the NW (Hoatson et al., 2008). Extension associated with Rodinia breakup likely led to the formation of some of the Central Australian Basin System. Development of this basin system, which began at c. $850 \mathrm{Ma}$ (Walter et al., 1995), and extended to the Devonian, affected most of central Australia and includes the Officer, Amadeus, Georgina and Yeneena basins as well as the Adelaide Rift System (Figure 2). These basins include the earliest known major salt deposits, in the Bitter Springs Formation of the Amadeus Basin, evidence for several periods of glaciation and the first flowering of multicellular life (see below). Deposition of the Bitter Springs and subsequent salt deposits around the world has lowered the salinity of seawater by at least a factor of 1.5-2 since the Neoproterozoic (Knauth, 2005).

Uranium and $\mathrm{Cu}$ deposits in the Yeneena Basin and the Adelaide Rift System formed between 840-790 Ma (Huston et al., 2010); these deposits were related to basin formation and/or inversion. Some reconstructions of Rodinia place Australia adjacent to the Kalahari Craton (Pisarevsky et al., 2003), which contains the highly productive Zambian Copper Belt (Selley et al., 2005). This belt is hosted by a basin of similar age and with similar fill to parts of the Central Australia Basin System; and the ages of ore deposition overlap.

\section{0-0 Ma: Amalgamation and breakup of Pangea-Gondwana}

The Phanerozoic, particularly the Paleozoic, was a period of extensive tectonic activity in Australia, particularly in the Tasman Element, which makes up the eastern third of the continent (Figure 2 ). This tectonic activity is related to the assembly and breakup of Pangea, a supercontinent that started to assemble at c. $600 \mathrm{Ma}$, was assembled by c. $250 \mathrm{Ma}$, and began to breakup shortly thereafter. Eastern Australia was always along an active margin during Pangea 
assembly. After c. $180 \mathrm{Ma}$, Pangea, and then Gondwana, began to break up, culminating with final separation of Australia from Antarctica at $34 \mathrm{Ma}$ (Veevers et al. 1991). Since $65 \mathrm{Ma}$, Australia has been relatively tectonically stable. Nevertheless, this stability will be relatively short lived in geological terms. Australia is currently moving northward, and is colliding with SE Asia as a prelude to the assembly of Amasia, interpreted by some as the world's next supercontinent (Santosh et al., 2009).

\section{0-250 Ma: Amalgamation of Gondwana and Laurasia to form Pangea}

Evolution of the Central Australian Basin System continued into the Paleozoic, recording evidence of major global ice ages, from the Yeneena Basin in Western Australia to the Adelaide Rift System in South Australia and King Island in Tasmania (Figure 2). Hoffman et al. (1998) suggested that these glacial events are representative of "Snowball Earth". During the late Neoproterozoic, the complexity of life increased such that towards the end of this era the first evidence of multicellular life appeared, including delicately preserved fossils in uppermost unit of the Pound Subgroup in the Ediacara Hills of the Adelaide Rift System (Glaessner and Wade, 1966). It is notable that these fossils began to flourish after the last of the Neoproterozoic glacial events.

The oldest activity in Australia related to Gondwana amalgamation was in Western Australia (Figure 12). Deformation at 650-600 Ma

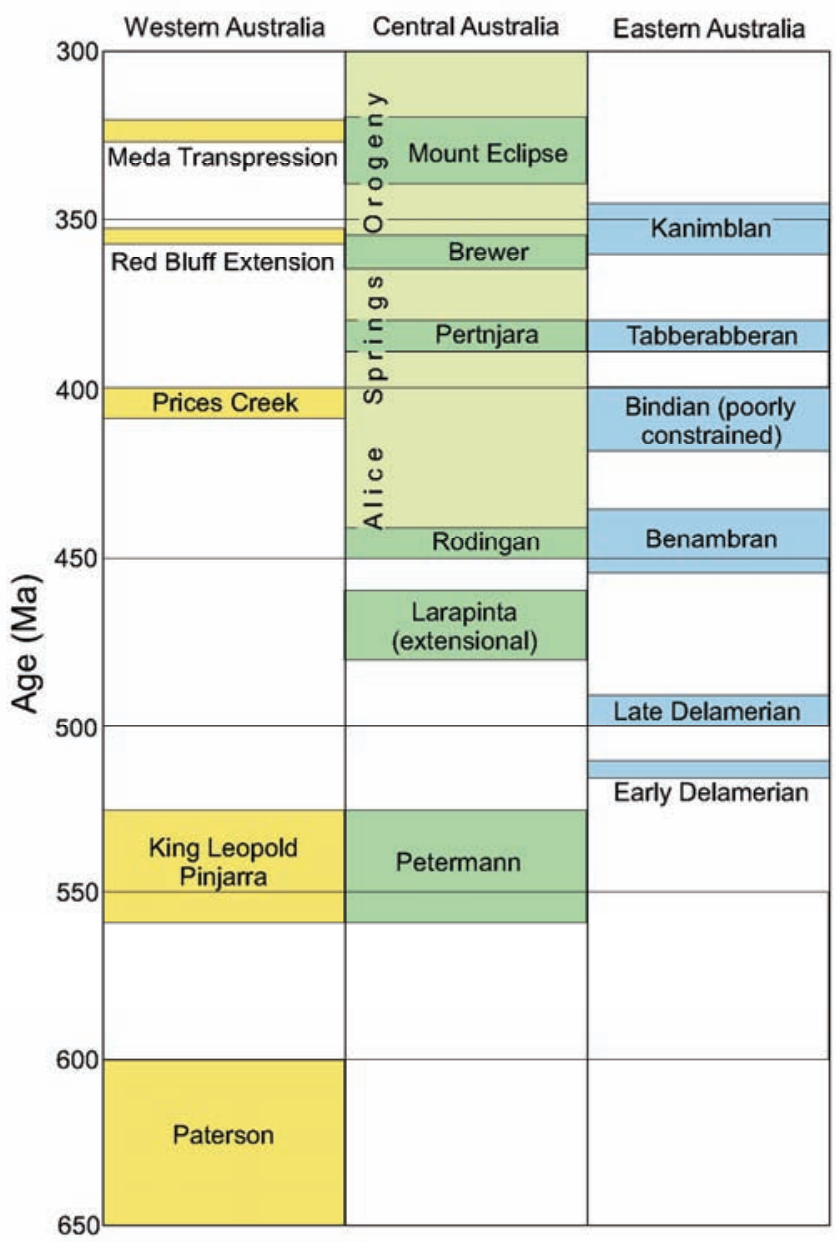

Figure 12 Space-time diagram showing the relationship of tectonic events in western, central and eastern Australia. was accompanied by granite emplacement and related $\mathrm{Cu}-\mathrm{Au}$ and $\mathrm{W}$ $\mathrm{Cu}-\mathrm{Zn}$ mineralisation in the Paterson Province (Goellnicht et al., 1989; Huston et al., 2010; Figure 13). More extensive deformation occurred between 560-525 Ma during the coeval King Leopold and Petermann orogenies, which affected and Kimberley and Musgrave provinces, respectively (Shaw et al., 1992; Aitken et al., 2011; and references therein). Zircon U-Pb discordia in the Tanami Province have similar lower intercept ages (Maidment, 2006), suggesting that the linked King Leopold-Petermann Orogeny extended from NW into central Australia (Figure 12). Aitken et al. (2011) suggested that the Petermann Orogeny is an intraplate response to the Kuunga Orogeny, which involved oblique collision between Australia and India during Gondwana assembly.

More direct evidence of Gondwana assembly is present along the southern part of the W coast of Australia, where the Pinjarra Orogen (Pinjarra Element) comprises elements of eastern Gondwana, notably the Australo-Antarctic and Indo-Antarctic domains. These represent distinct continental fragments with different Proterozoic histories that were juxtaposed through oblique collision by c. $522 \mathrm{Ma}$ (Collins, 2003a; Collins and Pisarevsky, 2005). The breakup of Gondwana has since re-separated these domains, although the fragments are still present in the Pinjarra Element (Boger, 2011). Immediately after the King Leopold, Petermann and Pinjarra orogenies, the c. $510 \mathrm{Ma}$ Kalkarindji large igneous province, one of the most extensive known, was emplaced through much of western and north-central Australia, possibly as a response to a mantle plume (Glass and Phillips, 2006).

In eastern Australia, the Tasman Element, which extends from Tasmania to northern Queensland, was built upon a passive margin formed by the breakup of Rodinia (Figure 14). This orogen is part of a global scale orogenic system, the Terra Australis Orogen that exceeded 18,000 km in length and extended along the margin of Gondwana (Cawood, 2005). The Tasman Element developed as the consequence of a sequence of tectonic cycles (Glen, 2005). Each of these cycles, which lasted between 30-130 Myr, initiated with arc magmatism and/or backarc extension, related, in most cases, to Wdipping subduction, and ended with contractional orogenesis as continental slivers and island arcs were accreted back onto the Australian continent (Gray and Foster, 2004; Collins and Richards, 2008). Five such cycles have been recognised (Glen, 2005; Champion et al., 2009): the Delamerian (515-490 Ma), Benambran (490-440 Ma), Tabberabberan (440-380 Ma; includes the Bindian), Kanimblan (380-350 Ma), and Hunter-Bowen (350-220 Ma). Although younger cycles overprint older cycles, particularly in N Queensland, the cycles broadly young eastwards. Collins (2003b) and Collins and Richards (2008) suggest that this cyclicity may relate to switching between long-lived subduction retreat, and associated extension, and shortlived subduction advance, and associated contraction.

There is a progression in the types of mineral deposits formed within individual cycles and an eastward progression in mineral system activity with time (Figure 13). Deposits formed in backarcs (e.g., volcanic-hosted massive sulfide deposits) formed early in cycles, whereas deposits that form mostly during contractional deformation (e.g., lode $\mathrm{Au}$ and structurally-hosted base metal deposits) formed late in the cycle. Juxtaposition of these mineral systems has resulted in a highly complex metallogeny through most of the Tasman Element, perhaps exemplified in western Tasmania, which is one of the richest and most diverse metallogenic provinces in the world, with major $\mathrm{Zn}-\mathrm{Pb}-\mathrm{Ag}-\mathrm{Cu}-\mathrm{Au}, \mathrm{Cu}-\mathrm{Au}, \mathrm{Au}, \mathrm{Sn}, \mathrm{W}$ and $\mathrm{Fe}$ deposits within a few tens of kilometres of each other (Green, 2012). Other important 


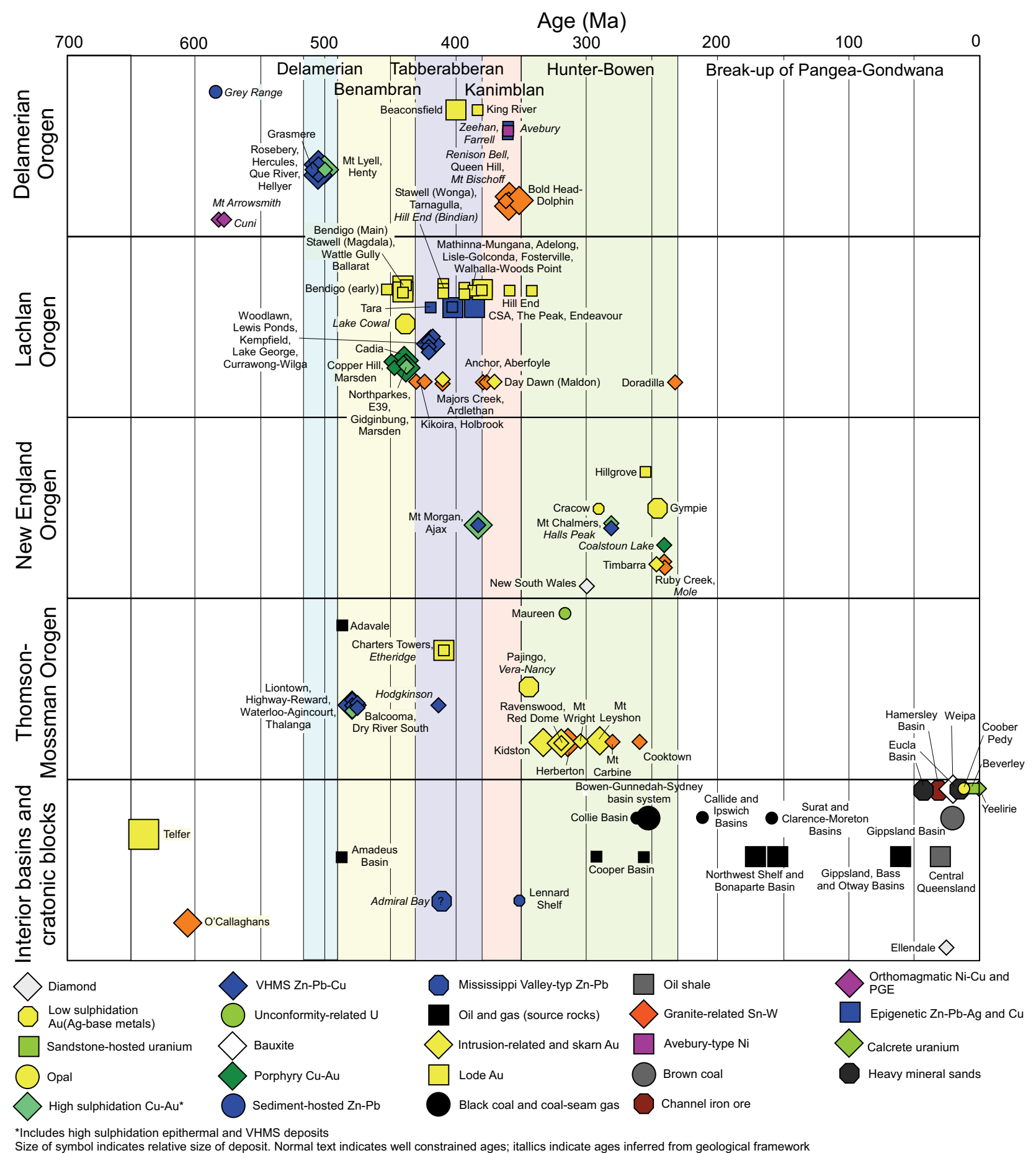

Figure 13 Major mineral deposits of Australia formed during the period 700-0 Ma, particularly during the assembly and break-up of Pangea-Gondwana. See Figure 2 for localities of named deposits. See Figure 2 for localities of named deposits and Figure 4 for explanation of acronyms and symbol size.

districts in the Tasman Element include lode Au deposits in the Victorian goldfields and at Charters Towers in N Queensland, and porphyry $\mathrm{Cu}-\mathrm{Au}$ deposits (e.g., Cadia) in the Macquarie Arc in New South Wales (Figure 2).

Central Australia underwent a series of intraplate deformational events during the Paleozoic. Many are time equivalent to events in the Tasman Element (Figure 12), suggesting that the activity related to convergence on the eastern seaboard also influenced the continent's interior. These central Australian events include development of the
Larapinta Seaway and the Alice Springs Orogeny. The Larapinta Seaway linked the Ordovician marine sediments of the Georgina and Amadeus basins through to the Gondwana margin in eastern Australia (Bradshaw, 1993; Figure 14a). These basins host the Larapintine petroleum system, which was sourced from organic-rich rocks deposited in warm and shallow, early Paleozoic seas (Bradshaw, 1993).

The 480-460 Ma Larapinta metamorphic event, which is characterised by granulite facies metamorphism, is an extensional event that is restricted to the Irindina Province (Hand et al., 1999; 

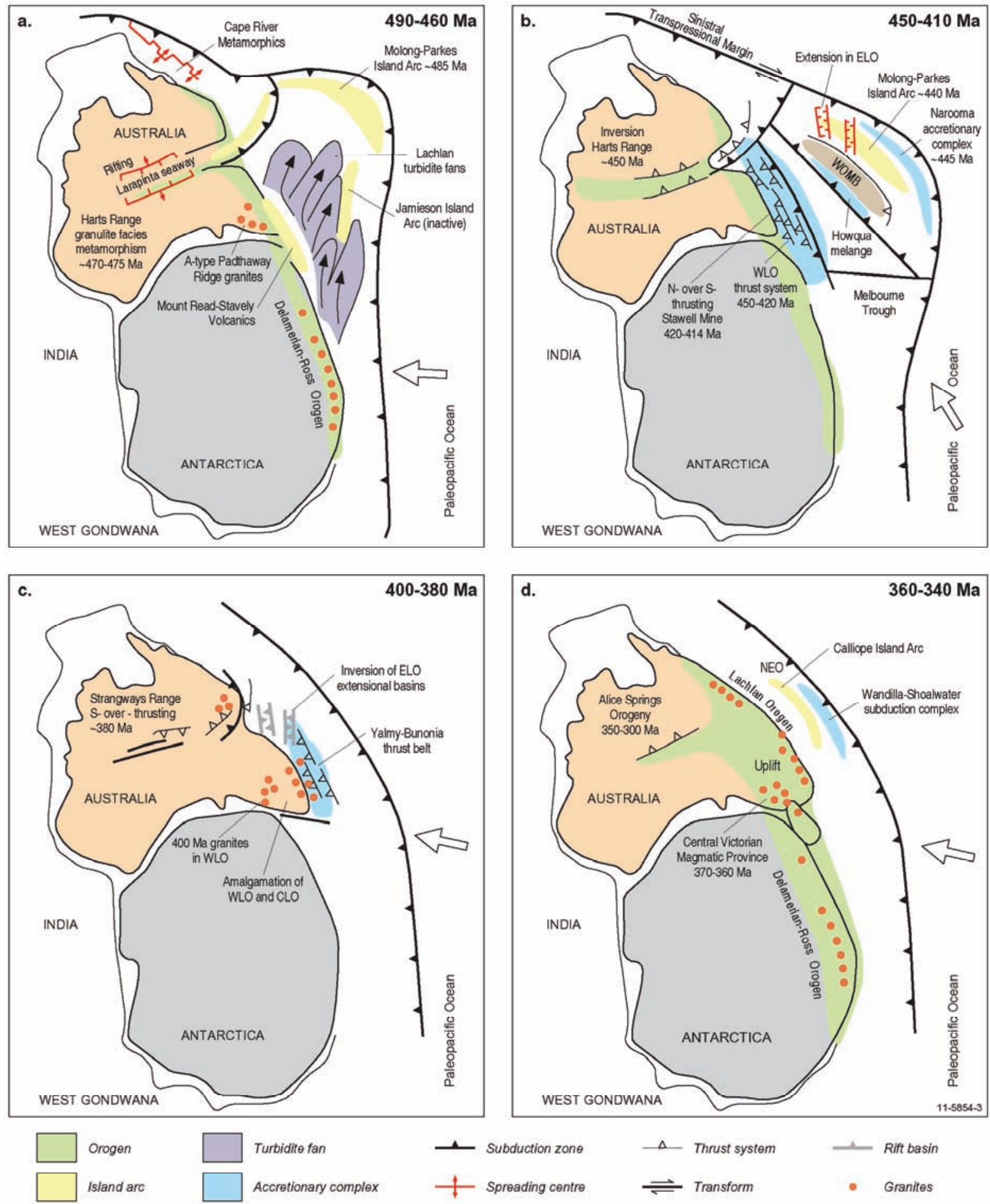

Figure 14 Schematic diagrams showing the tectonic evolution of Australia between 490-360 Ma (after Gray and Foster, 2004). ELO, CLO, WLO and NEO =Eastern Lachlan, Central Lachlan, Western Lachlan and New England orogens, respectively.

Maidment, 2005, 2006). This province is interpreted to be a deep (possibly to $30 \mathrm{~km}$ ), extensional sub-basin within the Larapintine Seaway, with tholeiitic basaltic rocks, which host semi-massive $\mathrm{Cu}-$ Co sulfide deposits, present near the base. Hoatson et al. (2005) suggested that these basaltic rocks formed in an extensional environment, and correlated them with the Antrim Plateau Volcanics of the Kalkarindji Large Igneous Province.

The Alice Springs Orogeny was a succession of four contractional events (or movements; Table 1), the 450-440 Ma Rodingan, 390-
380 Ma Pertnjara, 365-355 Ma Brewer and 340-320 Ma Mount Eclipse movements, which inverted large parts of the Larapinta Seaway (Gray and Foster, 2004; Scrimgeour and Close, 2011). During orogenesis, deep crustal rocks of the Irindina Province were exhumed from $30 \mathrm{~km}$ and juxtaposed with time-equivalent sub-greenschistgrade rocks in the Georgina Basin (Hand et al., 1999; Maidment, 2005; Korsch et al., 2011b). As part of this orogeny, the S-directed Redbank Shear Zone offset the Moho, creating one of the largest gravity anomalies (c. $150 \mathrm{mgal}$ ) from continental interiors on the Earth 


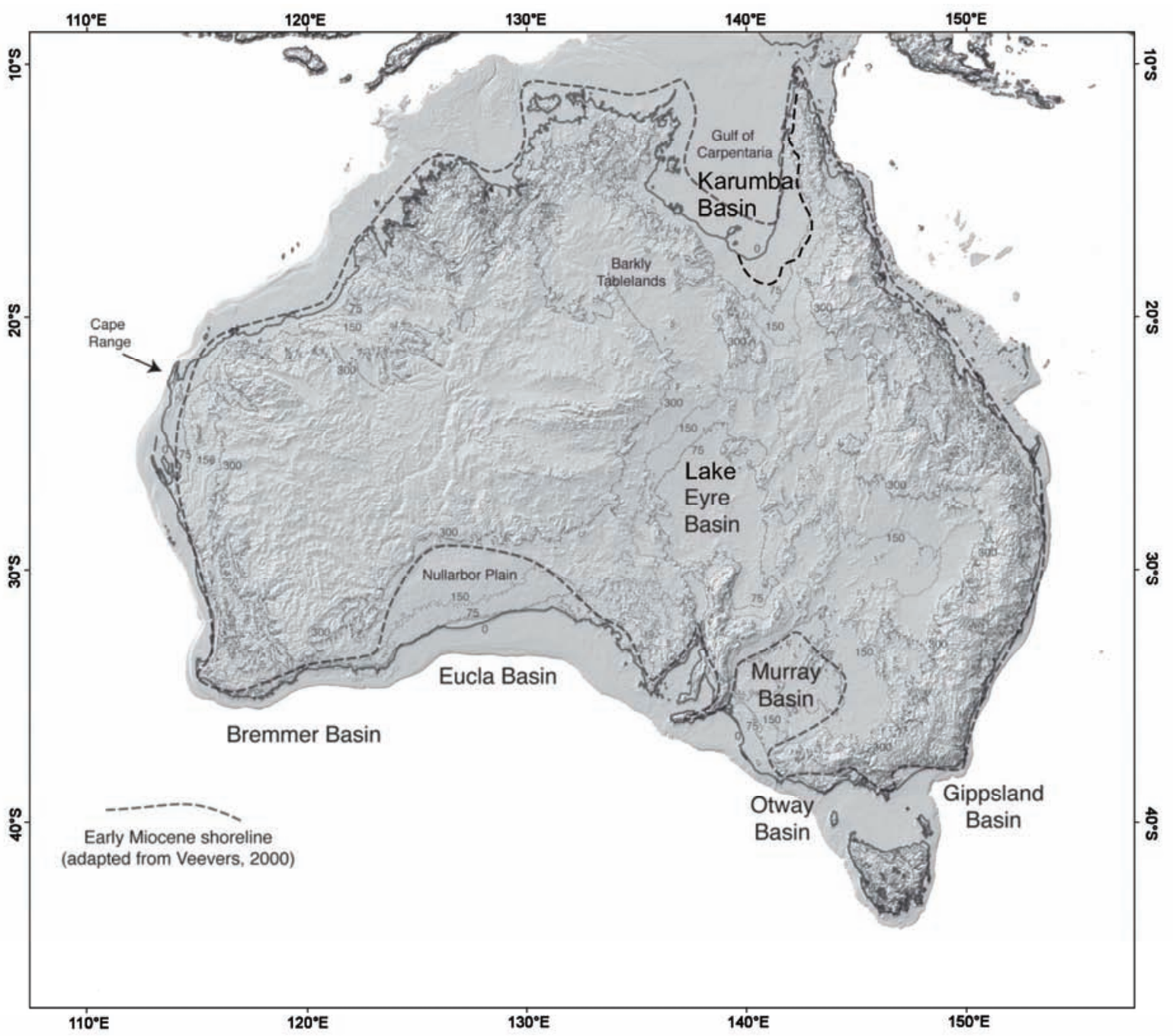

Figure 15 Distribution of Cenozoic basins in Australia over digital elevation model (modified after Sandiford et al., 2009).

(Mathur, 1976). Uplift and erosion associated with the Brewer Movement resulted in formation of a foreland basin (Haines et al., 2001) and may have driven hydrothermal flow that formed c. $357 \mathrm{Ma}$ (Christensen et al., 1995) Mississippi Valley-type Pb-Zn deposits in the Canning Basin of Western Australia.

Most of the vast coal deposits of the Sydney-Bowen-Gunnedah basin system in eastern Australia (Figure 2) formed in a Permian foreland basin behind a continental volcanic arc system that developed in the New England Orogen. Counter flow in the mantle wedge above the subduction zone is thought to have created a slowly subsiding basin that included thick coal measures (Waschbusch et al., 2009). The high-latitude position of Australia at this time, an environment similar to the modern Russian taiga, permitted the accumulation of vast amounts of peat from Glossopetris and other species (Veevers, 2006). These peat seams, accumulated over hundreds of thousands of years, and were compacted into black coal, with the thickest seams at Blair Athol being more than $31 \mathrm{~m}$ thick (Hobday, 1987).

\section{0-160 Ma: Stabilisation and breakup of Pangea}

After final amalgamation at c. $250 \mathrm{Ma}$, Pangea remained stable for less than $100 \mathrm{Myr}$ before it started to break apart. This breakup initiated at c. $180 \mathrm{Ma}$ as the Atlantic Ocean and Tethys Sea began to form, separating Gondwana, which included Australia, South America, Africa, India and Antarctica, from Laurasia, which included North America and Eurasia (Dietz and Holden, 1970). The emplacement of voluminous c. 175 Ma tholeiitic dolerite sills (Brauns et al., 2000) in Tasmania, which form part of the Karoo-Ferrar Large Igneous Province, presaged the breakup of Gondwana.

\section{0-65 Ma: Breakup of Gondwana and creation of Australia}

In the Late Jurassic, a triple point of extension, centred just SW of Perth in Western Australia, began to separate India, Antarctica and Australia (Veevers, 2006). The NW margin of Australia had formed by $155 \mathrm{Ma}$, when the last of a series of continental slivers (Argo Land, now in Burma) rifted away. Australia separated from Greater India by $120 \mathrm{Ma}$ (Norvick and Smith, 2001; Veevers, 2006) and the W coast faced the Indian Ocean.

Formation of major gas fields of the Westralian petroleum system on the North West Shelf are related directly to the breakup of Gondwana. Late Jurassic rifting along the NW-SE Westralian trend produced deep-marine depocentres into which organic-rich source rocks were deposited (Bradshaw, 1993). Clastic rocks of the Late 
Jurassic-Early Cretacoues Barrow delta, which formed as extension continued, buried the source rocks into the hydrocarbon-generating window and provided reservoir rocks. The seal was provided by extensive Cretaceous marine shales that were deposited after continental breakup (Bradshaw, 1993).

Australia separated from Antarctica via an easterly propagating rift system. Rift basins had begun to form as far E as the Polda Basin in South Australia at $155 \mathrm{Ma}$, and by $145 \mathrm{Ma}$ rifting in the Gippsland Basin in Victoria had occurred (Norvick and Smith, 2001). The submarine Kerguelen Large Igneous Province in the Southern Ocean was emplaced at c. $110 \mathrm{Ma}$ (Duncan, 2002). During the Jurassic and Cretaceous, a large inland sea covered central and eastern Australia, forming the Eromanga and related basins, which are as thick as $1,600 \mathrm{~m}$. These basins formed by dynamic changes to topography possibly caused by corner flow in the asthenosphere below eastern Australia during W-directed subduction (Waschbusch et al., 2009).

At $95 \mathrm{Ma}$, subduction jumped eastward, stopping the corner flow and triggering uplift of the eastern highlands of Australia (Waschbusch et al., 2009). The Eromanga Basin was inverted and began to erode, and a large delta system was deposited in the offshore Ceduna region, South Australia (Bradshaw, 1993; Norvick and Smith, 2001). By this time, a significant seaway had developed between Australia and Antarctica, although there was still connection through Tasmania. Extension associated with Australia-Antarctica breakup occurred between present-day Tasmania and Victoria to form a rift basin system that included the Otway, Bass and Gippsland basins, which cumulatively host one of Australia's main hydrocarbon provinces (Bradshaw, 1993).

Seafloor spreading along the E coast began c. $84 \mathrm{Ma}$ in the $\mathrm{S}$, and propagated northwards, resulting in the opening of the Tasman Sea and rifting off the Lord Howe Rise and New Zealand. By $56 \mathrm{Ma}$ the Tasman Sea ceased opening (Gaina et al., 1998). Sea floor spreading commenced further $\mathrm{N}$ with the Coral Sea opening and the Queensland Plateau rifting from the NE coast of Queensland (Weisel and Watts, 1979).

The long-term and deep weathering of Australia is one of its distinguishing features compared to northern hemisphere continents. Much of the weathering began as Gondwana broke apart. Oxygen isotope data indicate that clays produced during Mesozoic weathering formed in low latitudes as Australia began to move $\mathrm{N}$ from Antarctica (Chivas and Atlhopheng, 2010). By the end of the Cretaceous, the fundamental physiography and the paleovalley architecture in today's arid Australia was established (Fujioka and Chappell, 2010). Some of these paleo-land surfaces are as old as the Cambrian, but fission track dating suggests that some of these very ancient landscapes were buried and then more recently exhumed (Pillans, 2007).

\section{5-2.6 Ma: Australia girt by sea}

The past 65 Ma have left an indelible imprint on the Australian continent, with $80 \%$ of the surface geology of Australia made up of Cenozoic deposits. Most of the cover is thin aeolian, lacustrine and fluvial deposits, although many discrete basin entities developed, including the Eucla, Murray, Lake Eyre and the Karumba basins (Figure 15). Sea-floor spreading in the Southern Ocean accelerated at c. $45 \mathrm{Ma}$, but it was not until $34 \mathrm{Ma}$ that full separation of Australia and Antarctica was achieved (Zachos et al., 2001; Livermore et al., 2005). From c. 45-10 Ma, Cenozoic sediments were deposited in the
Lake Eyre, Eucla, Karumba, and Murray basins. The climate was warmer and wetter than today, and rainforests were extensive (Fujioka and Chappell, 2010). During this time, the sea made several incursions onto the land, forming, for example, Eocene (c. $40 \mathrm{Ma}$ ) and Miocene (15-5 Ma) shorelines that are preserved along the northern margins of the Eucla and Murray basins (Benbow et al., 1995). These marine incursions have left a legacy of paleoplacer deposits of rutile and other heavy minerals (Hou et al., 2003).

Between c. $45 \mathrm{Ma}-5 \mathrm{ka}$, Australia experienced episodic, mainly mafic magmatism that resulted in a series of volcanic provinces in the Tasman Element (O'Reilly and Zhang, 1995). Many of these volcanic provinces define what are interpreted as a series hot spot tracks that become younger to the $\mathrm{S}$ and track Australia's movement northward (Johnson et al., 1989). Others may be the consequence of upwelling of deep mantle (O’Reilly and Zhang, 1995).

Cenozoic basins, regolith, and paleovalleys host other resources, including Fe-ore, coal, oil shale, uranium, and groundwater. A significant proportion of the Fe-ore production from the Pilbara Craton comes from pisolitic iron that formed paleochannels, which were active at c. $30 \mathrm{Ma}$. These ores, derived originally from Paleoproterozoic banded-iron formation and $\mathrm{Fe}$ ore deposits, have been dated at between 28-5 Ma (Morris and Ramanaidou, 2007).

Brown coal deposits of the La Trobe Valley in SE Victoria, which provide most of that state's electricity, are as much as $130 \mathrm{~m}$ thick and formed between 30-20 Ma, when the climate was humid (Fujioka and Chappell, 2010). Similarly, the oil shale resources from pullapart, lacustrine basins near Gladstone and Proserpine in Queensland also formed at this time (Henstridge and Missen, 1982).

By $25 \mathrm{Ma}$, Australia and Antarctica had separated sufficiently to allow full circulation between the Southern Ocean and the Pacific Ocean, which resulted in major changes to the climate of Australia and Antarctica (Fujioka and Chappell, 2010). The great Antarctic ice sheet began to develop c. 15-10 Ma in the E and c. 10-6 Ma in the W and fundamentally altered the Earth's marine and terrestrial climate and sea levels. The impacts on Australia were large: meridional temperature gradients steepened, the subtropical monsoon contracted northwards, and the continent became drier. The boundaries between climatic zones strengthened, which led to the increased aridification of mid-latitude continental regions in Australia, as well as in Africa and North and South America. Grasslands developed, stimulating the evolution of grazing mammals, and in Australia the rainforests retreated (White, 1994; Fujioka and Chappell, 2010).

Active convergence, which is occurring today along Australia's northern margin, commenced at c. $40 \mathrm{Ma}$. Timor is now part of the Australian Plate and is moving northward along with Australia (Keep et al., 2002). The consequences of Australia's northward movement are best seen in New Guinea, on the northern margin of the plate. Collision with proto-Indonesia, and related fragments, emplaced the Irian ophiolite and created the present mountainous topography that forms the spine of New Guinea. An active fold-thrust belt has developed in the southern part of New Guinea, with the resulting foreland basins hosting major hydrocarbon accumulations at Tangguh, and Hides (Van Ufford and Cloos, 2005). The collision and underlying structure of the Australian Plate also control the location of Irian Jaya's and Papua New Guinea's giant Au deposits such as Grasberg and Ok Tedi (Hill et al., 2002; Davies, 2012).

Convergence and major dextral strike-slip faulting commenced c. $5 \mathrm{Ma}$ across the Australian Plate boundary in New Zealand. This resulted in far-field shortening in Australia and had an impact on the 
stress state, causing uplift in the Flinders Ranges, and contributing to Australia's present day earthquake hazard (Clark et al., 2011).

\section{6-0 Ma: The creation of modern Australia}

By 2.6 Ma, the beginning of the Quaternary Period, the current geology of Australia was mainly established. Australia had separated from Gondwana and was moving northward towards SE Asia, setting up the stress field that is prevalent today. Hence, the most significant changes observed in Quaternary Australia are not related to tectonics, but to climate and the arrival of humans. The Quaternary in Australia is characterised by repeated episodes of aridity linked to glacialinterglacial cycles. In Tasmania, the maximum ice extent occurred at c. $1 \mathrm{Ma}$, with later advances in the past $100 \mathrm{ka}$ being less extensive. These glacial periods were accompanied by periods of aridity: there was an intensification of atmospheric circulation, a reduction in atmospheric moisture and an increase in continentality, thereby leading to more arid conditions (Fujioka and Chappell, 2010). These conditions resulted in deflation and the formation of vast areas of sand dunes. Today, $40 \%$ of the Australian arid zone is mantled by aeolian sand dunes and sand plains (Haberlah et al., 2010).

Lake Eyre, in South Australia, reached its maximum water levels at $130-110 \mathrm{ka}$, with particularly low levels at $95-80 \mathrm{ka}$ and at $65-$ $62 \mathrm{ka}$. The last glacial maximum saw Lake Eyre completely dry and exposed to the wind, which scoured its base and deepened the lake floor (Hesse, 2010).

Continental Australia was $10^{\circ} \mathrm{C}$ cooler at $22 \mathrm{ka}$ than now. It was also much drier and windier and sea level was $120 \mathrm{~m}$ lower (Fujioka and Chappell, 2010), creating land bridges from the mainland to Papua New Guinea and to Tasmania. The climate warmed, sea levels rose, and the land bridges were swamped by $6 \mathrm{ka}$. Palynological data record the return of warmer and wetter climatic conditions, which saw the tropical rain forests expand between 8-6 ka and again at $3 \mathrm{ka}$ (Fujioka and Chappell, 2010).

Aboriginal and Torres Strait Islander people have occupied Australia since at least 60-45 ka (Roberts et al., 1990; Pope and Terrell, 2008), and were present during many of the major climate changes that have affected Australia during the latter part of the Quaternary. These changes had major impacts on the Aboriginal people. Changes in climate caused episodic occupation of specific sites as consequences of availability of water and food and changes in sea level. For example, Shark Bay, $800 \mathrm{~km} \mathrm{~N}$ of Perth, was occupied during three distinct periods, between 30-18 ka, between 7-6 ka and since c. $2.3 \mathrm{ka}$ (Bowdler, 1999). A far greater consequence of climate change was the isolation of Tasmanian Aboriginal people. Tasmania was first inhabited at c. $40 \mathrm{ka}$ when a land bridge existed between it and the mainland. This land bridge was severed at c. 8 ka when sea level rose in association with interglacial warming (Pardoe et al., 1991). This isolated Tasmania until the arrival of Europeans just before the turn of the 19th century.

\section{The future: Toward Amasia}

The next supercontinent, Amasia, is expected to be fully formed within a 250 Myr time period (Santosh et al., 2009). The Australian continent, including Papua New Guinea, is currently colliding with the Indonesian archipelago. This convergence has and will continue to produce natural resources, as is currently occurring in Papua New Guinea and Indonesia. Hydrocarbon deposits will continue to form in foreland sedimentary basins related to fold-thrust belts.

\section{Conclusions}

The geological evolution of Australia is a fascinating microcosm of the evolution of Earth. This evolution is closely linked to the supercontinent cycle, with most geological and metallogenic events relating to the assembly and breakup of Vaalbara, Kenorland, Nuna, Rodinia and Pangea-Gondwana. In a broad sense, Australia grew from $\mathrm{W}$ to E, with two major Archean cratons, the Yilgarn and Pilbara cratons, forming the oldest part of the continent in the West Australian Element. The centre is dominated by the mainly PaleoproterozoicMesoproterozoic North and South Australian elements, whereas the E is dominated by the Phanerozoic Tasman Element. The West, North and South Australian elements initially appear to have been assembled during the Paleoproterozoic amalgamation of Nuna, although the resulting proto-Australia subsequently partially broke-up and was then reassembled during Rodinia amalgamation. The Tasman Element formed mostly during the Paleozoic when the eastern margin of Australia was an active, accretionary margin during the assembly of Gondwana, and then Pangea. Australia's present position as a relatively stable continent, with passive margins on three sides, is the result of its final break-away from Gondwana, when its link to Antarctica was fully severed at $34 \mathrm{Ma}$. It is presently moving northward toward SE Asia, probably during the earliest stages of the assembly of the next supercontinent, Amasia.

Australia's resources, both mineral and energy, are linked to its tectonic evolution and the supercontinent cycle. Although the mineral and energy resources are known throughout Australia and their formation spans its history, there is a strong clustering of resources both in time and in space and these clusters are associated with the Earth's supercontinent cycles. Australia's most important Au province, the Eastern Goldfields in Western Australia, is the product of the assembly of Kenorland, whereas major PaleoproterozicMesoproterozoic $\mathrm{Zn}-\mathrm{Pb}-\mathrm{Ag}$ deposits and the giant Olympic Dam iron oxide- $\mathrm{Cu}-\mathrm{Au}$ deposits formed as Nuna broke up. The diverse metallogeny of the Tasman Element is a product of Pangea-Gondwana assembly and most of Australia's hydrocarbon resources are a consequence of the breakup of this supercontinent. Very young $\mathrm{Au}$ and $\mathrm{Cu}-\mathrm{Au}$ deposits in Papua New Guinea and Indonesia to the $\mathrm{N}$ of Australia may be the very early products of Amasia assembly.

\section{Acknowledgements}

This paper has benefited from discussions and collaborations with colleagues from Geoscience Australia, Australian State and Territory Geological Surveys and academia. The paper has also benefited from reviews by Peter Betts, Brendan Brooke, Peter Cawood, George Gibson, David Giles, Richard Goldfarb, John Kennard, Russell Korsch, Anya Reading, Ian Roach and Phil Symonds. This contribution is published with the permission of the Chief Executive Officer of Geoscience Australia. 


\section{References}

Aitken, A.R.A., Betts, P.G. and Ailleres, L., 2011, The architecture, kinematics, and lithospheric processes of a compressional intraplate orogen occurring under Gondwana assembly: The Petermann orogeny, central Australia: Lithosphere, v. 1, pp. 343-357.

Bagas, L., 2004, Proterozoic evolution and tectonic setting of the northwest Paterson Orogen, Western Australia: Precambrian Research, v. 128, pp. 475-496.

Bagas, L., Bierlein, F.P., English, L., Anderson, J.A.C., Maidment, D. and Huston, D.L., 2008, An example of a Palaeoproterozoic back-arc basin: Petrology and geochemistry of the ca. 1864 Ma Stubbins Formation as an aid towards an improved understanding of the Granites-Tanami Orogen, Western Australia: Precambrian Research, v. 166, pp. 168-184.

Barley, M.E., Sylvester, G.C. and Groves, D.I., 1984, Archaean calc-alkaline volcanism in the Pilbara Block, Western Australia: Precambrian Research, v. 96 , pp. $285-319$

Barley, M.E., Eisenlohr, B., Groves, D.I., Perring, C.S. and Vearncombe, J.R., 1989, Late Archaean convergent margin tectonics and gold mineralization: a new look at the Norseman-Wiluna Belt: Geology, v. 17, pp. 826-829.

Barley, M.E., Pickard, A.L., Hagemann, S.G., and Folkert, S.L., 1999, Hydrothermal origin for the 2 billion year old Mount Tom Price giant iron ore deposit, Hamersley Province, Western Australia: Mineralium Deposita, v. 34, pp. 784-789.

Barley, M.E., Bekker, A., and Krapez, B., 2005, Late Archean to early Proterozoic global tectonics, environmental change and the rise of atmospheric oxygen: Earth and Planetary Sciences Letters, v. 238, pp. 156-171.

Baross, J.A. and Hoffman, S.E., 1985, Submarine hydrothermal vents and associated gradient environments as sites for the origin and evolution of life: Origins of Life, v. 15, pp. 327-345.

Beardsmore, T.J., Newberry, S.P. and Laing, W.P., 1988, The Maronan Supergroup: an inferred early volcanosedimentary rift sequence in the Mount Isa Inlier, and its implications for ensialic rifting in the Middle Proterozoic of northwest Queensland: Precambrian Research, v. 40/41, pp. 487-507.

Bekker, A., Slack, J.F., Planavsky, N., Krapez, B., Hofman, A., Konhauser, K.O. and Rouxel, O.J., 2010, Iron formation: the sedimentary product of a complex interplay among mantle, tectonic, oceanic, and biospheric processes: Economic Geology, v. 105, pp. 467-508.

Benbow, M.C., Lindsay, J.M. and Alley, N.F., 1995, Eucla Basin and palaeodrainage: Geological Survey of South Australia, Bulletin, v. 54, pp. $178-186$.

Betts, P.G. and Giles, D., 2006. The 1800-1100 Ma tectonic evolution of Australia: Precambrian Research, v. 144, pp. 92-125.

Betts, P.G., Giles, D. and Lister, G.S., 2003, Tectonic environment of shalehosted massive sulfide $\mathrm{Pb}-\mathrm{Zn}-\mathrm{Ag}$ deposits of Proterozoic northeastern Australia: Economic Geology, v. 98, pp. 557-576.

Betts, B.G., Giles, D., Schaefer, B.F. and Mark, G., 2007, A 1600-1500 Ma hotspot track in eastern Australia: implications for Mesoproterozoic continental reconstructions: Terra Nova, v. 19, pp. 496-501.

Betts, P.G., Giles, D. and Schaefer, B.F., 2008, Comparing 1800-1600 Ma accretionary and basin processes in Australia and Laurentia: possible geographic connections in Columbia: Precambrian Research, v. 166, pp. 81-92.

Bickle, M.J., Bettenay, L.F., Barley, M.E., Chapman, H.J., Groves, D.I., Campbell, I.H. and de Laeter, J.R., 1983, A 3500 Ma plutonic and volcanic calc-alkaline province in the Archaean East Pilbara Block: Contributions to Mineralogy and Petrology, v. 84, pp. 25-35.

Blewett, R.S., 2002, Archaean Tectonic Processes: a case for horizontal shortening in the North Pilbara Granite-Greenstone Terrane, Western Australia: Precambrian Research, v. 113, pp. 87-120.

Blewett, R.S. Henson, P.A. Roy, I.G. Champion, D.C. Cassidy. K.F., 2010, Scale-integrated architecture of a world-class gold mineral system: The Archaean eastern Yilgarn Craton, Western Australia: Precambrian Research, v. 183, pp. 230-250.
Boger, S.D., 2011, Antarctica - before and after Gondwana: Gondwana Research, v. 19, pp. 335-371.

Bowdler, S. 1999. Research at Shark Bay, WA, and the nature of coastal adaptations in Australia, in Hall, J. and McNiven, I. (eds), Australian Coastal Archaeology: Publications, Australian National University, Canberra, pp. 79-84.

Bradley, D., 2008, Passive margins through earth history: Earth Science Reviews, v. 91, pp. 1-26.

Bradshaw, M., 1993, Australian petroleum systems: PESA Journal, v. 21, pp. 43-53.

Brauns, C.M., Hergt, J.M., Woodhead, J. D. and Maas, R., 2000, Os isotopes and the origin of the Tasmanian dolerites: Journal of Petrology, v. 41, pp. $905-918$.

Buick, R., Thornett, J.R., McNaughton, N.J., Smith, J.B., Barley, M.E. and Savage, M., 1995, Record of emergent continental crust $\sim 3.5$ billion years ago in the Pilbara Craton of Australia: Nature, v. 375, pp. 574-577.

Cawood, P.A., 2005, Terra Australis Orogen: Rodinia breakup and development of the Pacific and Iapetus margins of Gondwana during the Neoproterozoic and Paleozoic: Earth Science Reviews, v. 69, pp. 249279 .

Cawood, P.A. and Korsch, R.J., 2008, Assembling Australia: Proterozoic building of a continent: Precambrian Research, v. 166, pp. 1-35.

Cawood, P.A. and Tyler, I.M., 2004, Assembling and reactivating the Proterozoic Capricorn Orogen: lithotectonic elements, orogenies, and significance: Precambrian Research, v. 128, pp. 201-218.

Champion, D.C. and Smithies, R.H., 2007, Geochemistry of Paleoarchean granites of the East Pilbara Terrane, Plibara Craton, Western Australia: implications for earth Archean crustal growth: Developments in Precambrian Geology, v. 15, pp. 369-409.

Champion, D.C., Kositcin, N., Huston, D.L., Mathews, E. and Brown, C., 2009, Geodynamic synthesis of the Phanerozoic of eastern Australia and implications for metallogeny: Geoscience Australia, Record 2009/18, 254 pp.

Chivas, A.R. and Atlhopheng, J.R., 2010, Oxygen-isotope dating the Yilgarn regolith: Geological Society, London, Special Publications, v. 346, pp. 309-320.

Christensen, J.N., Halliday, A.N., Vearncombe, J.R. and Kesler, S.E., 1995, Testing models of large-scale crustal fluid flow using direct dating of sulfides: $\mathrm{Rb}$-Sr evidence of early dewatering and formation of MVT deposits, Canning Basin, Australia: Economic Geology, v. 90, pp. 887884 .

Claoué-Long, J.C. and Hoatson, D. M., 2005, Proterozoic mafic-ultramafic intrusions in the Arunta Region, central Australia. Part 2: event chronology and regional correlations: Precambrian Research, v. 142, pp. 134-158.

Clark, D., McPherson, A. and Collins, C.D.N., 2011, Australia's seismogenic neotectonic record: Geoscience Australia, Record 2011/11, 95 pp.

Cloud, P., 1973, Paleoecological significance of banded iron-formation: Economic Geology, v. 68, pp. 1135-1143.

Collins, A.S., 2003a, Structure and age of the northern Leeuwin Complex, Western Australia: constraints from field mapping and U-Pb analysis: Australian Journal of Earth Sciences, v. 50, pp. 585-599.

Collins, A.S. and Pisarevsky, S.A., 2005, Amalgamating eastern Gondwana: the evolution of the Circum-Indian Orogens: Earth Science Reviews, v. 71, pp. 229-270.

Collins, W.J., 2003b, Hot orogens, tectonic switching, and creation of continental crust: Geology, v. 30, pp. 535-538.

Collins, W.J. and Richards, S.W., 2008, Geodynamic significance of S-type granites in Circum-Pacific orogens: Geology, v. 36, pp. 559-562.

Compston, D., 1995, Time constraints on the evolution of the Tennant Creek Block, northern Australia: Precambrian Research, v. 71, pp. 107-129.

Compston, D.M. and Matthai, S.K., 1994, Age constraints on early Proterozoic gold deposits, Pine Creek Inlier and Tennant Creek Inlier, northern Australia: Geological Society of Australia, Abstracts, v. 37, pp. 70.

Condie, K.C., 2005, Earth as an evolving planetary system: Elsevier, Amsterdam.

Couper, R.A., 1960, Southern hemisphere Mesozoic and Tertiary Podocarpaceae and Fagaceae and their palaeogeographic significance: 
Proceedings of the Royal Society of London, Series B, Biological Sciences, v. 152, pp. 491-500.

Cross, A., Fletcher, I.R., Crispe, A.J., Huston, D.L. and Williams, N., 2005, New constraints on the timing of deposition and mineralisation in the Tanami Group: Northern Territory Geological Survey, Record 2005-001, pp. $185-192$.

Cutts, K., Hand, M. and Kelsey, D.E., 2011, Evidence for early Mesoproterozoic (ca. $1590 \mathrm{Ma}$ ) ultrahigh-temperature metamorphism in southern Australia: Lithos, v. 124, pp. 1-18.

Czarnota, K., Champion, D.C., Goscombe, B., Blewett, R.S., Cassidy, K.F., Henson, P.A. and Groenewald, P.B., 2010, Geodynamics of the eastern Yilgarn Craton: Precambrian Research, v. 183, pp. 175-202.

Davies, H.L., 2012, Geology of New Guinea -the cordilleran margin of the Australian continent: Episodes (this volume).

Dietz, R.S. and Holden, J.C., 1970, Reconstruction of Pangaea: breakup and dispersion of continents, Permian to present: Journal of Geophysical Research, v. 75, pp. 4939-4956.

Duncan, R.A., 2002, A time frame for construction of the Kerguelen Plateau and Broken Ridge: Journal of Petrology, v. 43, 1109-1119.

Duncan, R.J., Stein, H.J., Evans, K.A., Hitzman, M.W., Nelson, E.P. and Kirwin, D.J., 2011, A new geochronological framework for mineralization and alteration in the Selwyn-Mount Dore corridor, Eastern Fold Belt, Mount Isa Inlier, Australia: genetic implications for iron oxide coppergold deposits: Economic Geology, v. 106, pp. 169-192.

Etheridge, M.A., Rutland, R.W.R. and Wyborn, L.A.I., 1987, Orogenesis and tectonic processes in the Early to Middle Proterozoic of northern Australia: American Geophysical Union Geodynamic Series, v. 17, pp. 131-147.

Farquhar, J., Wu, N., Canfield, D.E. and Oduro, H., 2010, Connections between sulfur cycle evolution, sulfur isotopes, sediments, and base metal sulfide deposits: Economic Geology, v. 105, pp. 509-534.

Fooden, J., 1972, Breakup of Pangaea and isolation of relict mammals in Australia, South America and Madagascar: Science, v. 175, pp. 894898.

Fraser, G.L., McAvaney, S., Neumann, N., Szpunar, M. and Reid, A.J., 2010, Discovery of early Mesoarchean crust in the eastern Gawler Craton, South Australia: Precambrian Research, v. 179, pp. 1-21.

Fujioka, T. and Chappell, J., 2010, History of Australian aridity: chronology in the evolution of arid landscapes: Geological Society of London, Special Publications, v. 346; pp. 121-139.

Gaina, C., Muller, D.R., Royer, J-Y., Stock, J., Hardebeck, J. and Symonds, P., 1998, The tectonic history of the Tasman Sea: a puzzle with 13 pieces: Journal of Geophysical Research, v. 103, pp. 12413-12433.

Geological Survey of Queensland, 2011, North-west Queensland mineral and energy province report: Brisbane, Queensland Department of Employment, Economic Development and Innovation, 123 pp.

Gibson, G.M., Rubenach, M., Neumann, N.L., Southgate, P.N. and Hutton, L.J., 2008, Syn- and post-extensional tectonic activity in the Palaeoproterozoic sequences of Broken Hill and Mount Isa and its bearing on reconstructions of Rodinia: Precambrian Research, v. 166, pp. 350369.

Giles, D., Betts, P. and Lister, G., 2002, Far-field continental backarc setting for the 1.80-1.67 Ga basins of northeastern Australia: Geology, v. 30, pp. 823-826.

Giles, D., Betts, P.G. and Lister, G.S., 2004, 1.8-1.5-Ga links between the North and South Australian Cratons and the Early-Middle Proterozoic configuration of Australia: Tectonophysics, v. 380, pp. 27-41.

Glaessner, M.F. and Wade, M., 1966, The Late Precambrian fossils from Ediacara, South Australia: Palaeontology, v. 9, pp. 599-628.

Glass, L.M. and Phillips, D., 2006, The Kalkarindji continental flood basalt province: A new Cambrian large igneous province in Australia with possible links to faunal extinctions: Geology, v. 36, pp. 461-464.

Glen, R.A., 2005, The Tasmanides of eastern Australia: Geological Society of London, Special Publications, v. 246, pp. 23-96.

Goellnicht, N.M., Groves, D.I., McNaughton, N.J. and Dimo, G., 1989, An epigeneitic origin for the Telfer gold deposit: Economic Geology, Monograph, v. 6, pp. 151-167.
Goleby, B.R., Huston, D.L., Lyons, P., Vandenberg, L., Bagas, L., Davies, B.M., Jones, L.E.A., Gebre-Mariam, M., Johnson, W., Smith, T. and English, L., 2009, The Tanami deep seismic reflection experiment: An insight into gold mineralization and Paleoproterozoic collision in the North Australian Craton: Tectonophysics, v. 472, pp. 169-182.

Gray, D.R. and Foster, D.A., 2004, Tectonic review of the Lachlan Orogen, southeast Australia: historical review, data synthesis and modern perspectives: Australian Journal of Earth Sciences, v. 51, pp. 773-817.

Green, G.R., 2012, Ore deposits and metallogenesis of Tasmania: Episodes (this volume).

Haberlah, D., Glasby, P., Williams, M.A.J., Hill, S.M., Williams, F. Rhodes, E.J., Gostin, V., O'Flaherty, A. and Jacobsen, G.E., 2010, 'Of droughts and flooding rains': an alluvial loess record from central South Australia spanning the last glacial cycle: Geological Society of London, Special Publications, v. 346, 185-223.

Haines, P.W., Hand, M. and Sandiford, M., 2001, Palaeozoic syn-orogenic sedimentation in central and northern Australia: a review of distribution and timing with implications for intracontinental orogens: Australian Journal of Earth Sciences, v. 48, pp. 911-928.

Hand, M., Mawby, J., Kinny, P. and Foden, J., 1999, U-Pb ages from the Harts Range, central Australia: evidence for early Ordovician extension and constraints on Carboniferous metamorphism: Journal of the Geological Society of London, v. 156, pp. 715-730.

Hawkesworth, C.J., Dhuime, B., Pietranik, A.B., Cawood, P.A., Kemp, A.I.S. and Storey, C.D., 2010, The generation and evolution of the continental crust: Journal of the Geological Society of London, v. 167, pp. 229-248.

Henstridge, D.A. and Missen, D.D., 1982, Geology of oil-shale deposits within the Narrows Graben, Queensland, Australia: AAPG, Bulletin, v. 66, pp. 719-731.

Hesse, P.P., 2010. The Australian desert dunefields: formation and evolution in an old, flat, dry continent: Geological Society of London, Special Publications, v. 346, pp. 141-164.

Hickman, A.H. and Van Kranendonk, M.J., 2012, Early Earth evolution: evidence from the 3.5-1.8 Ga geological history of the Pilbara region of Western Australia: Episodes (this volume).

Hill, K.C., Kendrick, R.D., Crowhurst, P.V. and Gow, P.A. 2002. Coppergold mineralisation in New Guinea: tectonics, lineaments, thermochronology and structure: Australian Journal of Earth Sciences, v. 49 , pp. $737-752$.

Hoatson, D.M., Sun, S.-S. and Claoué-Long, J.C., 2005, Proterozoic maficultramafic intrusions in the Arunta Region, central Australia: Part 1: Geological setting and mineral potential: Precambrian Research, v. 142, pp. 93-133.

Hobday, D.K., 1987, Gondwana coal basins of Australia and South Africa: tectonic setting, depositional systems and resources. Geological Society of London, Special Publications, v. 32, pp. 219-233.

Hoffman, P.F., 1991, Did the breakout of Laurentia turn Gondwana inside out? Science, v. 252, pp. 1409-1412.

Hoffman, P.F., Kaufman, A.J., Halverson, G.P. and Shrag, D.P., 1998, A Neoproterozoic snowball Earth: Science, v. 281, pp. 1342-1346.

Hollis, J.A., Glass, L.M., Carson, C.J., Armstrong, R., Yaxley, G., Kemp, A.I.S., Schersten, A. and Phillips, D., 2011, The geological evolution of the Pine Creek Orogen: new pieces in the puzzle on orogen and craton scale: Northern Territory Geological Survey, Record 2011-002, pp. 1825.

Hou, B., Frakes, L.A., Alley, N.F. and Heithersay, P., 2003, Evolution of beach placer shorelines and heavy-mineral deposition in the eastern Eucla Basin, South Australia: Australian Journal of Earth Sciences, v. 50, pp. 955965.

Hussey, K.J., Huston, D.L. and Claoué-Long, J.C., 2005, Geology and origin of some $\mathrm{Cu}-\mathrm{Pb}-\mathrm{Zn}(\mathrm{Au}-\mathrm{Ag})$ deposits in the Strangways Metamorphic Complex, Arunta region Northern Territory: Northern Territory Geological Survey, Report, v. 17.

Huston, D.L. and Logan, G.A., 2004, Barite, BIFs and bugs: Evidence for the evolution of the Earth's early hydrosphere: Earth and Planetary Science Letters, v. 220, pp. 41-55. 
Huston, D.L., Morant, P., Pirajno, F., Cummins, B., Baker, D. and Mernagh, T.P., 2007, Paleoarchean mineral deposits of the Pilbara Craton: genesis, tectonic environment and comparison with younger deposits: Developments in Precambrian Geology, v. 15, pp. 369-409.

Huston, D.L., Czarnota, K., Jaireth, S., Williams, N.C., Maidment, D., Cassidy, K.F., Duerden, P. and Miggins, D., 2010, Mineral systems of the Paterson region: Geoscience Australia, Record 2010/12, pp. 155-218.

Idnurm, M., 2000, Towards a high resolution Late Palaeoproterozoic-earliest Mesoproterozoic apparent polar wander path for northern Australia: Australian Journal of Earth Sciences, v. 47, pp. 405-429.

Jackson, M.J., Powell, T.G., Summons, R.E. and Sweet, I.P., 1986, Hydrocarbon shows and petroleum source rocks in sediments as old as 1.7 x $10^{9}$ years: Nature, v. 322, pp. 727-729.

Johnson, R.W., Knutson, J. and Taylor, S.R. (eds), 1989, Intraplate volcanism in Eastern Australia and New Zealand: Cambridge, Cambridge University Press, 408 pp.

Keep, M., Clough, M. and Langhi, L., 2002, Neogene tectonic and structural evolution of the Timor Sea region, NW Australia, in Keep, M. and Moss, S. (eds), The Sedimentary Basins of Western Australia III, Proceedings West Australian Basins Symposium: PESA, Perth, pp. 341-353.

Kinny, P.D., Williams, I.S., Froude, D.O., Ireland, T.R. and Compston, W., 1988, Early Archaean zircon ages from orthogneisss and anorthosites at Mount Narryer, Western Australia: Precambrian Research, v. 38, pp. 325341.

Kirkland, C.L., Spaggiari, C.V., Pawley, M.J., Wingate, M.T.D., Smithies, R.H., Howard, H.M., Tyler, I.M., Belousova, E.A. and Poujol, M., 2011, On the edge: $\mathrm{U}-\mathrm{Pb}, \mathrm{Lu}-\mathrm{Hf}$, and $\mathrm{Sm}-\mathrm{Nd}$ data suggest reworking of the Yilgarn craton margin during formation of the Albany-Fraser Orogen: Precambrian Research, v. 187, pp. 223-247.

Knauth, L.P., 2005, Temperature and salinity history of the Precambrian ocean: implications for the course of microbial evolution: Palaeogeography, Palaeoclimatology, Palaeoecology, v. 219, pp. 53-69.

Korenaga, J., 2006, Archean geodynamics and the thermal evolution of Earth: American Geophysical Union Geophysical Monograph, v. 164, pp. 732.

Korsch, R.J., Kositcin, N. and Champion, D.C., 2011a, Australian island arcs through time: geodynamic implications for the Archean and Proterozoic: Gondwana Research, v. 19, pp. 716-734.

Korsch, R.J., Blewett, R.S., Close, D.F., Scrimgeour, I.R., Huston, D.L., Kositcin, N., Whelan, J.A., Carr, L.K. and Duan, J.-M., 2011b, Geological interpretation and geodynamic implications of the deep seismic reflection and magnetotelluric line 09GA-GA1: Georgina Basin-Arunta Region, Northern Territory: Northern Territory Geological Survey, Record 2011003, pp. 67-76

Korsch, R.J., Huston, D.L, Henderson, R.A., Blewett, R.S., Withnall, I.W., Fergusson, C.L., Collins, W.J., Saygin, E., Kositcin, N., Meixner, A.J., Chopping, R., Henson, P.A., Champion, D.C., Hutton, L.J., Wormald, R., Holzschuh, J. and Costelloe, R.D., 2012, Crustal architecture and geodynamics of North Queensland, Australia: insights from deep seismic reflection profiling: Tectonophysics (in press).

Krapez, B. and Barley, M.E.B., 2008, Late Archaean synorogenic basins of the Eastern Goldfields Superterrane, Yilgarn Craton, Western Australia. Part III. Signatures of tectonic escape in an arc-continent collision zone: Precambrian Research, v. 161, pp. 183-199.

Leach, D.L., Bradley, D.C., Huston, D.L., Pisarevsky, S.A., Taylor, R.D. and Gardoll, S.J., 2010, Sediment-hosted lead-zinc deposits in Earth history: Economic Geology, v. 105, pp. 593-625.

Livermore, R., Nakivell, A., Eagles, G. and Morris, P., 2005, Paleogene opening of Drake Passage: Earth and Planetary Science Letters, v. 236, pp. 459470 .

Maidment, D.W., 2005, Palaeozoic high-grade metamorphism within the Centralian Superbasin, Harts Range region, central Australia: $\mathrm{PhD}$ thesis, Australian National University (unpublished).

Maidment, D., 2006, Post-1570 Ma intracratonic reworking of the North Australian Craton: Geoscience Australia, Record 2006/16, pp. 11-12.

Mathur, S.P., 1976, Relation of Bouguer anomalies to crustal structure in southwestern and central Australia: BMR Journal of Australian Geology and Geophysics, v. 1, pp. 277-286.

McCuaig, T.C., Behn, M., Stein, H., Hagemann, S.G., McNaughton, N.J., Cassidy, K.F., Champion, D.C. and Wyborn, L., 2001, The Boddington gold mine: a new style of Archaean Au-Cu deposit: Geoscience Australia, Record 2001/37, pp. 453-455.

McDonald, G.D., Collerson, K.D. and Kinny, P.D., 1997, Late Archaean and Early Proterozoic crustal evolution of the Mount Isa block, northwest Queensland, Australia: Geology, v. 25, pp.1095-1098.

Morris, R.C. and Ramanaidou, E.R., 2007, Genesis of the channel iron deposits (CID) of the Pilbara region, Western Australia: Australian Journal of Earth Sciences, v. 54, pp. 733-756.

Müller, S.G., Krapez, B., Barley, M.E. and Fletcher, I.R., 2005, Giant ironore deposits of the Hamersley province related to the breakup of Paleoproterozoic Australia: new insights from in situ SHRIMP dating of baddeleyite from mafic intrusions: Geology, v. 33, pp. 577-580.

Myers, J.S., Shaw, R.D. and Tyler, I.M., 1996. Tectonic evolution of Proterozoic Australia: Tectonics, v. 15, pp. 1431-1446.

Nelson, D.R., Trendall, A.F. and Altermann, W., 1999, Chronological correlations between the Pilbara and Kaapvaal cratons: Precambrian Research, v. 97, pp. 165-189.

Neumann, N., Sandiford, M. and Foden, J., 2000, Regional geochemistry and continental heat flow: implications for the origin of the South Australian heat flow anomaly: Earth and Planetary Science Letters, v. 183 , pp. $107-120$

Nisbet, E.G., Cheadle, M.J., Arndt, N.T. and Bickle, M.J., 1993, Constraining the potential temperature of the Archaean mantle: A review of the evidence from komatiites: Lithos, v. 30, pp. 291-307.

Norvick, M.S. and Smith, M.A., 2001. Mapping the plate tectonic reconstruction of Southern and Southeastern Australia and implications for petroleum systems: APEA Journal, v. 49, pp. 15-35.

O'Reilly, S.Y. and Zhang, M., 1995, Geochemical characteristics of lavafield basalts from eastern Australia and inferred sources: connections with the subcontinental lithospheric mantle: Contributions to Mineralogy and Petrology, v. 121, pp. 148-170.

Pardoe, C., Bowdler, S., Brace, C.L., Plomley, N.J.B., Turner, C.G., II and Wolfpoff, M.H., 1991, Isolation and Evolution in Tasmania [and Comments and Reply]: Current Anthropology, v. 32, pp. 1-21.

Page, R.W., Conor, C.H.H., Stevens, B.P.J., Gibson, G.M., Preiss, W.V. and Southgate, P.N., 2005, Correlation of Olary and Broken Hill Domains, Curnamona Province: possible relationship to Mount Isa and other North Australian Pb-Zn-Ag-bearing successions: Economic Geology, v. 100, pp. 663-676.

Payne, J.L., Barovich, K. and Hand, M., 2006, Provenance of metasedimentary rocks in the northern Gawler Craton, Australia: implications for Paleoproterozoic reconstructions: Precambrian Research, v. 148, pp. 275 291

Payne, J.L., Hand, M., Barovich, K.M., Reid, A. and Evans, D.A.D., 2009, Correlations and reconstruction models for the 2500-1500 Ma evolution of the Mawson Continent: Geological Society of London, Special Publications, v. 323, pp. 319-355.

Pidgeon, R.T., Smith, C.R. and Fanning, C.M., 1989, Kimberlite and lamproite emplacement ages in Western Australia: Geological Society of Australia, Special Publication, v. 14, pp. 369-381.

Pillans, B., 2007, Pre-Quaternary landscape inheritance in Australia: Journal of Quaternary Science, v. 22 pp. 439-447.

Pisarevsky, S.A., Wingate, M.T.D., Powell, C. McA., Johnson, S. and Evans, D.A.D., 2003, Models of Rodinia assembly and fragmentation: Geological Society of London, Special Publications, v. 206, pp. 35-55.

Pope, K.O. and Terrell, J.E., 2008. Environmental setting of human migrations in the circum-Pacific region: Journal of Biogeography, v. 35, pp. 1-21.

Qiu, Y., Groves, D.I. and McNaughton, N.J., 1997, Deep-seated granitoids: implications for Late Archaean subduction-collision-lithospheric delamination and gold mineralization in the Yilgarn Craton. Australian Geological Survey Organisation, Record 1997/41, pp. 65-69.

Rasmussen, B. and Buick, R., 2000, Oily old ores: evidence for hydrothermal 
petroleum generation in an Archean volcanogenic massive sulfide deposit: Geology, v. 28, pp. 731-774.

Roberts, R.G., Jones, R. and Smith, M.A., 1990. Thermoluminescence dating of a 50,000-year-old human occupation site in northern Australia: Nature, v. 345 , pp. $153-156$.

Rubatto, D., Williams, I.S. and Buick, I.S., 2001, Zircon and monazite response to prograde metamorphism in the Reynolds Range, central Australia: Contributions to Mineralogy and Petrology, v. 140, pp. 458468.

Sandiford, M., Quigley, M., De Broekert, P. and Jakica, S., 2009, Tectonic framework for the Cenozoic cratonic basins of Australia: Australian Journal of Earth Sciences, v. 56, pp. 5-18.

Santosh, M., Maruyama, S. and Yamamoto, S., 2009, The making and breaking of supercontinents: some speculations based on superplumes, super downwelling and the role of the tectosphere: Gondwana Research, v. 15 , pp. 324-341.

Scott, D.L., Rawlings, D.J., Page, R.W., Tarlowski, C.Z., Idnurm, M., Jackson, M.J. and Southgate, P.N., 2000, Basement framework and geodynamic evolution of the Palaeoproterozoic superbasins of north-central Australia: An integrated review of geochemical, geochronological and geophysical data: Australian Journal of Earth Sciences, v. 47, pp. 341-380.

Scrimgeour, I. R. and Close, D.F., 2011, Overview of the geology and tectonics along the Georgina-Arunta seismic traverse: Northern Territory Geological Survey, Record 2011-003, pp. 57-62.

Scrimgeour, I.R., Kinny, P.D., Close, D.F. and Edgoose, C.J., 2005, High-T granulites and polymetamorphism in the southern Arunta region, central Australia: evidence for a $1.64 \mathrm{Ga}$ accretional event: Precambrian Research, v. 142, pp. 1-27.

Selley, D., Broughton, D., Scott, R., Hitzman, M., Bull, S., Large, R., McGoldrick, P., Croaker, M., Pollington, N. and Barra, F., 2005, A new look at the geology of the Zambian copper belt: Economic Geology, 100th Anniversary Volume, pp. 965-1000.

Sewell, D.M., 1999, The Koongie Park and Little Mount Isa zinc-copperlead deposits East Kimberley Region: Geological Survey of Western Australia, Mineral Resources Bulletin 15, pp. 139-155.

Shaw, R.D., Tyler, I.M., Griffin, T.J. and Webb, A., 1992, New K-Ar constraints on the onset of subsidence in the Canning Basin, Western Australia: BMR Journal of Australian Geology and Geophysics, v. 13, pp. 31-55.

Sheppard, S., Tyler, I.M., Griffin, T.J. and Taylor, W.R., 1999, Palaeoproterozoic subduction-related and passive margin basalts in the Halls Creek orogen, northwest Australia: Australian Journal of Earth Sciences, v. 46, pp. 679-690.

Skirrow, R.G., 2010. 'Hematite-group' IOCG \pm U ore systems: Tectonic settings, hydrothermal characteristics, and $\mathrm{Cu}-\mathrm{Au}$ and $\mathrm{U}$ mineralizing processes: Geological Association of Canada Shortcourse Notes, v. 20, pp. 3958 .

Skirrow, R.G., Bastrakov, E.N., Barovich, K, Fraser, G.L, Creaser, R.A., Fanning, C.M., Raymond, O.L. and Davidson, G.J., 2007, Timing of iron oxide $\mathrm{Cu}-\mathrm{Au}-(\mathrm{U})$ hydrothermal activity and $\mathrm{Nd}$ isotopic constraints on metal sources in the Gawler Craton, South Australia: Economic Geology, v. 102, pp. 1441-1470.

Smithies, R.H., Champion, D.C. and Van Kranendonk, M.J., 2005a, It started with a plume - early Archaean basaltic proto-continental crust: Earth and Planetary Science Letters, v. 238, pp. 284-297.

Smithies, R.H., Champion, D.C., Van Kranendonk, M.J., Howard, H.H. and Hickman, A.H., 2005b, Modern-style subduction processes in the Mesoarchean: geochemical evidence from the $3.12 \mathrm{Ga}$ Whundo intraoceanic arc: Earth and Planetary Science Letters, v. 231, pp. 221227.

Smithies, R.H., Howard, H.M., Evins, P.M., Kirkland, C.L., Kelsey, D.E., Hand, H., Wingate, M.T.D., Collins, A.S., Belousova, E. and Allchurch, S., 2010, Geochemistry, geochronology and petrogenesis of Mesoproterozoic felsic rocks in the western Musgrave Province of central Australia, and implications for the Mesoproterozoic tectonic evolution of the region: Geological Survey of Western Australia, Report 106, $73 \mathrm{pp}$.
Southgate, P.N., Bradshaw, B.E., Domagala, J., Jackson, M.J., Idnurm, M., Krassay, A.A., Page, R.W., Sami, T.T., Scott, D.L., Lindsay, J.F., McConachie, B.A. and Tarlowski, C., 2000, Chronostratigraphic basin framework for Palaeoproterozoic rocks (1730-1575 Ma) in northern Australia and implications for mineralisation: Australian Journal of Earth Sciences, v. 47, pp. 461-485.

Stein, H.J., Markey, R.J., Morgan, J.W., Selby, D., Creaser, R.A., McCuaig, T.C. and Behn, M., 2001, Re-Os dating of Boddington molybdenite, SW Yilgarn: two Au mineralization events: Geoscience Australia, Record 2001/37, pp. 469-471

Swain, G., Barovich, K., Hand, M., Ferris, G.J. and Schwarz, M., 2008, Petrogenesis of the St Peter Suite, southern Australia: arc magmatism and Proterozoic crustal growth of the South Australian Craton: Precambrian Research, v. 166, pp. 283-296.

Taylor, D., Dalstra, H.J., Harding, A.E., Broadbent, G.C. and Barley, M.E., 2001, Genesis of high-grade hematite orebodies of the Hamersley Province, Western Australia: Economic Geology, v. 96, pp. 837-873.

Tyler, I.M. and Sheppard, S., 2006, Geology and mineralisation of the King Leopold and Halls Creek Orogens: Geosciences Australia, Record 2006/ 16 , pp. 51-52.

Van Kranendonk, Hickman, A.H., M.J., Smithies, R.H., Nelson, D.R. and Pike, G., 2002, Geology and tectonic evolution of the Archean North Pilbara Terrain, Pilbara Craton, Western Australia: Economic Geology, v. 97 , pp. 695-732.

Van Kranendonk., M.J., Philippot, P., Lepot, K., Bodorkos, S. and Pirajno, F., 2008, Geological setting of Earth's oldest fossils in the ca. $3.5 \mathrm{Ga}$ Dresser Formation, Pilbara Craton, Western Australia: Precambrian Research, v. 167, pp. 93-124.

Van Ufford A.Q. and Cloos, M., 2005, Cenozoic tectonics of New Guinea: AAPG Bulletin, v. 89, pp. 119-140.

Veevers, J.J., 2006, Updated Gondwana (Permian-Cretaceous) earth history of Australia: Gondwana Research, v. 9, pp. 231-260.

Veevers, J., Powell, C. and Roots, S., 1991, Review of seafloor spreading around Australia. Synthesis of the patterns of spreading: Australian Journal of Earth Sciences, v. 38, pp. 373-389.

Wade, B.P., Barovich, K.M., Hand, M., Scrimgeour, I.R. and Close, D.F., 2006, Evidence for early Mesoproterozoic arc magmatism in the Musgrave Block, central Australia: implications for Proterozoic crustal growth and tectonic reconstructions of Australia: Journal of Geology, v. 114 , pp. 43-63.

Walter, M.R., Buick, R. and Dunlop, J.S.R., 1980, Stromatolites, 3,400-3,500 Myr old from the North Pole area, Western Australia: Nature, v. 284, pp. 443-445.

Walter, M.R., Veevers, J.J., Calver, C.R. and Gray, K., 1995, Neoproterozoic stratigraphy of the Centralian Superbasin, Australia: Precambrian Research, v. 73, pp. 173-195.

Waschbusch, P., Korsch, R.J. and Beaumont, C., 2009, Geodynamic modelling of aspects of the Bowen, Gunnedah, Surat and Eromanga Basins from the perspective of convergent margin processes: Australian Journal of Earth Sciences, v. 56, pp. 309-334.

Weissel, J.K. and Watts, A.B., 1979, Tectonic evolution of the Coral Sea Basin: Journal of Geophysical Research, v. 84, pp. 4572-4582.

White, M.E., 1994, After the Greening, the Browning of Australia: Kangaroo Press, Kenthurst, NSW.

Wilde, S.A., Valley, J.W., Peck, W.H. and Graham, C.M., 2001, Evidence from detrital zircons for the existence of continental crust and oceans on the Earth 4.4 Gyr ago: Nature, v. 409, pp. 175-178.

Willis, I.L., Brown, R.E., Stroud, W.J. and Stevens, B.J.P., 1983, The early Proterozoic Willyama Supergroup: stratigraphic subdivision and interpretation of high to low-grade metamorphic rocks in the Broken Hill block, New South Wales: Journal of the Geological Society of Australia, v. 30, pp. 195-224.

Wingate, M.T.D., Campbell, I.H., Compston W. and Gibson, G.M., 1998, Ion microprobe $\mathrm{U}-\mathrm{Pb}$ ages for Neoproterozoic basaltic magmatism in southcentral Australia and implications for the breakup of Rodinia: Precambrian Research, v. 87, pp. 135-159. 
Wingate, M.T.D., Pisarevsky, S.A. and Evans, D.A.D., 2002, A revised Rodinia supercontinent: no SWEAT, no AUSWUS: Terra Nova, v. 14, pp. 121128.

Zachos, J., Pagani, M., Sloan, L., Thomas, E. and Billups, K., 2001, Trends, rhythms, and aberrations in global climate $65 \mathrm{Ma}$ to present: Science, v. 292, pp. 686-693.

Zegers, T.E., White, S.H., de Keijzer, M., Dirks, P., 1996, Extensional structures during deposition of the 3460 Ma Warrawoona Group in the eastern Pilbara Craton, Western Australia: Precambrian Research, v. 80, pp. 89-105.

Zegers, T.E., de Wit, M.J., Dann, J. and White, S.H., 1998, Vaalbara, the Earth's oldest assembled continent? A combined structural, geochronological, and paleomagnetic test: Terra Nova, v. 10, pp. 250259.

Zhao, J-X. and McCulloch, M.T., 1995, Geochemical and Nd isotopic systematics of granites from the Arunta Inlier, central Australia: implications for Proterozoic crustal evolution: Precambrian Research, v. 71 , pp. $265-299$.

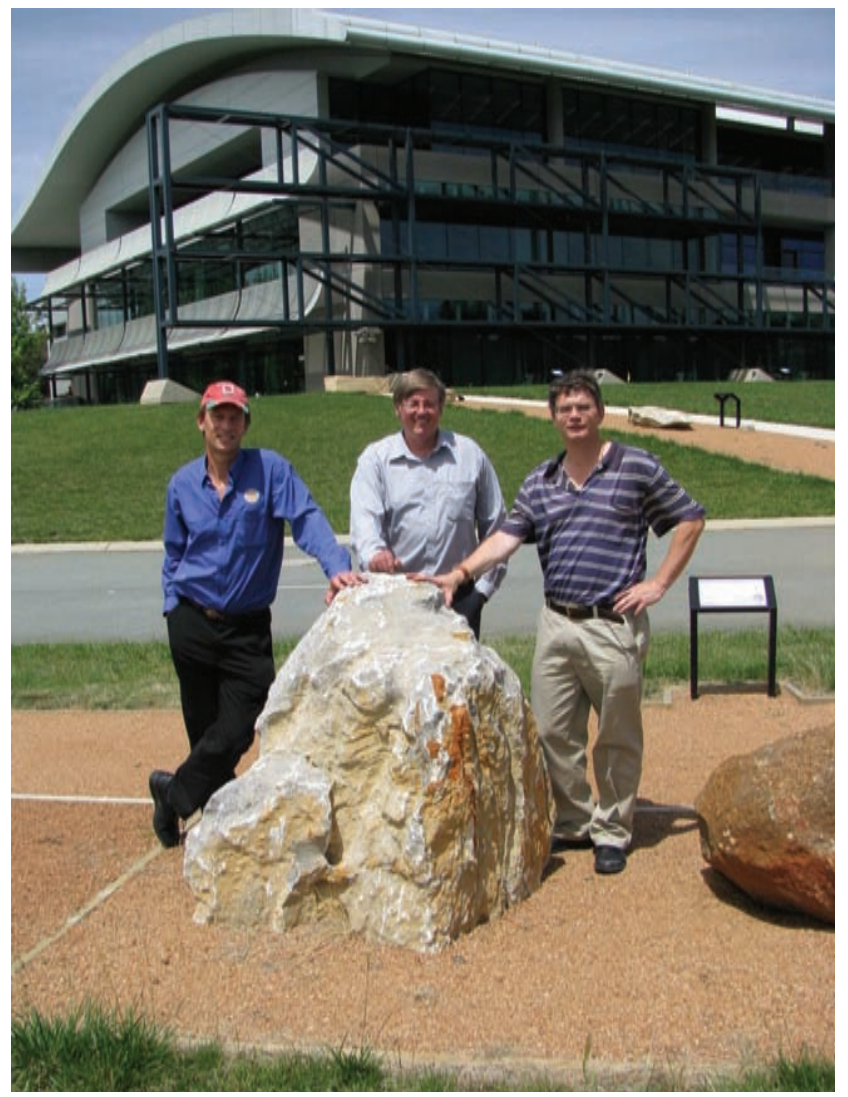

David Huston (right), a research scientist at Geoscience Australia (pictured in background), has interests in metallogenesis, the ages of ore deposits, and the relationship of mineralisation to secular changes in tectonics and the composition of the hydrosphere. He has worked on a range of deposit types with ages from the Paleoarchean through the Cenozoic, with a special interest in volcanic-hosted massive sulfide deposits. He joined Geoscience Australia in 1995 and has since worked in the North Pilbara Terrane, the Aileron, Tanami and Mount Isa provinces of the North Australian Element, the Paterson Province, and the Tasman Orogen.

Richard Blewett (left) is Australian-born but graduated from Swansea University (Wales) in 1995. He completed his PhD in structural geology from Leicester University, UK. During this time he did fieldwork in the Appalachians, Caledonides and Himalayas. Richard joined Geoscience Australia in 1990 and has worked on the tectonics and mineral systems of Northeast Queensland, North Pilbara, Sultanate of Oman, Eastern Goldfields (WA), Gawler-Curnamona, central Australia and Capricorn Orogen (WA). He is interested in the management of science and research and has an MBA from Deakin University (2001).

David Champion (centre) graduated from ANU and joined Geoscience Australia in 1992, working on Archean to Phanerozoic granites of Australia, their genesis and mineral potential, and implications for continental growth and geodynamic environments. During the last 10 years, his focus has shifted towards understanding secular changes in these granites and in geodynamic environments within Australia. This has included studies of the heat producing elements through time and implications for geothermal energy. 